
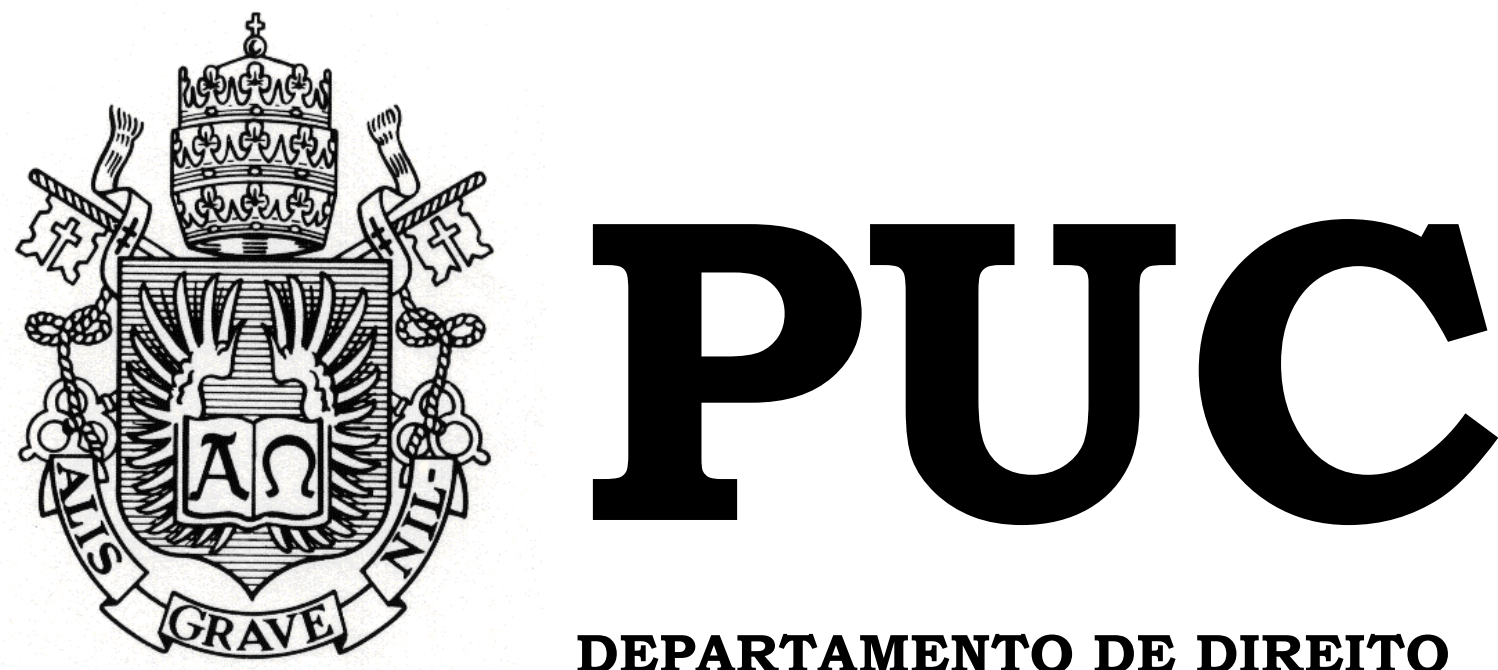

DEPARTAMENTO DE DIREITO

\title{
ANÁlise DA ADEQUAÇÃO DO PROJETO DE ASSENTAMENTO ROSELI NUNES À NOVA LEGISLAÇÃO AMBIENTAL
}

\author{
por
}

FELIPE HERMETO DE ALMEIDA

ORIENTADORA: MARIANA TROTTA

DALLALANA QUINTANS

2015.1

PONTIFÍCIA UNIVERSIDADE CATÓLICA DO RIO DE JANEIRO

RUA MARQUÊS DE SÃO VICENTE, 225 - CEP 22453-900

RIO DE JANEIRO - BRASIL 


\section{ANÁlISE dA ADEQUAÇÃO DO PROJETO \\ DE ASSENTAMENTO ROSELI NUNES À}

\section{NOVA LEGISLAÇÃO AMBIENTAL}

por

FELIPE HERMETO DE ALMEIDA

Monografia apresentada ao Departamento de Direito da Pontifícia Universidade Católica do Rio de Janeiro (PUC-Rio) para a obtenção do Título de Bacharel em Direito.

Orientadora: Mariana Trotta Dallalana Quintans 


\section{AGRADECIMENTOS}

Primeiramente, gostaria de agradecer a todos os assentados do Projeto de Assentamento Roseli Nunes, não só por receberem os estudantes da PUC-Rio e permitirem tantas trocas e experiência, mas também por lutarem pela justiça social, pela distribuição de terra, por um país e uma sociedade mais igualitários, e deixar acessa a esperança na mudança.

À Doutora Mariana Trotta, minha orientadora na presente pesquisa. Por ter aceitado o desafio de me orientar, por dar visibilidade às demandas sociais no espaço universitário, em um trabalho de conscientização tão importante em tempos de tanto estigma, reacionarismo e desesperança.

Em seguida, gostaria de dizer que nada disso seria possível sem a instrução de Mestres como Adriano Pilatti e Adriana Geisler, que coordenam (junto à Prof ${ }^{a}$. Trotta) o Núcleo Direitos em Movimento da PUC-Rio, e despertam seus estudantes para a cruel realidade da construção de desigualdades históricas que ainda se desenrolam em violações de direitos, marginalização, violência estatal e estado de exceção. Que possam instruir muitas gerações na luta por uma sociedade mais justa.

Fundamental para o desenrolar da presente pesquisa foi a participação da equipe técnica de obtenção e da de desenvolvimento do Instituto Nacional de Colonização e Reforma Agrária (INCRA) no Rio de Janeiro, em especial ao Professor Rodrigo Alcantara, Carlos Alberto, Rovena Louzada, Azélio, Neilor e Igor, que muito me auxiliaram, com todo o acúmulo que detém em suas respectivas áreas.

Agradecer também a toda a equipe NIMA: aos diretores Luiz Felipe Guanaes e Fernando Walcacer, que me inspiraram, cada um à sua maneira, a trilhar o estudo ambiental interdisciplinar . Em especial à Professora Virginia Totti, que me auxiliou muito, quase me co-orientando, nas questões ambientais do presente trabalho.

Não poderia deixar de agradecer aos meus avós e à minha Mãe, pelo suporte que me deram ao longo destes 7 anos de graduação. 


\section{RESUMO}

O espaço agrário comporta hoje muitas diferentes realidades: desde o agronegócio latifundiário, passando pela agricultura familiar empresarial, a agricultura familiar campesina, populações ribeirinhas, indígenas, quilombolas entre outras. Neste cenário é violenta a disputa por terras, e portanto, diferentes modelos de produção e reprodução do capital. A produtividade das terras, dentro da lógica convencional hegemônica (monoculturas de exportação, modernização conservadora, introdução de tecnologias e cultivos estrangeiras nos ecossistemas locais com baixa adaptação), sobre a qual discorre-se também ao longo da presente investigação, identifica os ecossistemas nativos como barreira à produção, baseando-se nas colheitas de alta credibilidade e escoamento no mercado, conhecidas internacionalmente como cash crops(colheitas de dinheiro produções voltadas para o mercado internacional de commodities como soja, milho - que hoje são em sua maioria transgênicos - em boa parte responsáveis pelo desmatamento e expansão ilegal da fronteira agrícola).

Diante desta perspectiva, pode-se concluir que as defesas legais relativas aos espaços territoriais especialmente protegidos são usualmente consideradas pelo senso comum como restritivas à produção, amplamente estruturada em moldes estrangeiros de baixa interação com os serviços ecossistêmicos locais. Não obstante as restrições legais constatava-se (e ainda constata-se) no território brasileiro diversas propriedades que, tanto por desinformação, ou necessidade, ou mera conveniência não respeitavam a legislação florestal e os espaços protegidos por lei. Baseando-se nesse contexto de irregularidade generalizada - em torno de $90 \%$ dos agricultores do país - o deputado federal Aldo Rebelo do PCdoB, em 08 de junho de 2010 apresentou seu parecer como Relator do Projeto de Lei 1876/99, que em 25 de maio de 2012 viria a ser aprovado como a Lei 12.651, no qual afirmava que era necessária a flexibilização de certas proteções ambientais e o perdão ao desmatamento em um projeto controverso que afirmava, 
regularizaria a situação de muitos produtores rurais (tanto pequenos produtores, ribeirinhos quanto grandes produtores agroindustriais).

O objetivo do presente trabalho é analisar como e em que medida o Novo Código Florestal afeta as dinâmicas espaciais do assentamento Roseli Nunes, do MST em Piraí, onde a comunidade PUC-Rio mantém atividades de intercâmbio e pesquisa, e tentar identificar se estas mudanças legislativas beneficiaram ou não a coletividade deste assentamento de pequenos produtores, uma vez que eram estas também o público-alvo almejado pelas políticas de regularização ambiental na retórica parlamentar que construiu a Lei 12.651 .

Palavras-chave: Reforma Agrária; Novo Código Florestal; Projeto de Assentamento Roseli Nunes 


\section{ABSTRACT}

The agrarian space holds many different realities today: from agribusiness, to family companies agriculture, peasant family agriculture, riverside populations, indigenous, afro-descendant communities amongst others. In this scenario the dispute for land is violent and therefore, for different production models and capital reproduction. The land productivity, inside the hegemonic conventional logic, (export monocultures, conservative modernization, introduction of foreign crops and technology in our local ecosystems with low adaptation) which will also be discussed through the present investigation, identifies the native ecosystems as a barrier to production, based in high credibility and outflow, internationally known as cash crops (commodities such as soy and corn - which are in its majority, genetically modified - that are responsible for good part of deforestation and the illegal expansion of the agrarian frontier)

Before such perspective, we can conclude that the legal defenses related to specially protected territorial spaces are considered by the common sense as restricting the production, which is structured in foreign molds with low interaction with the local ecossystemic services. Even counting the legal restrictions, it could be verified in the brasilian territory that many properties, because of disinformation, necessity or mere convenience did not respect the forest legislation and its protected spaces. In such context of generalized irregularity - approximately $90 \%$ of the country's farmers - the federal Depute Aldo Rebelo of the Communist Party of Brasil (PC do B), presented, in 2010, his feedback as Comptroller of the Law Project number 1876/99 that came to be approved in 2012 as Law $\mathrm{n}^{\circ} 12651$, in which he affirms to be necessary to give flexibility to certain environmental protections and to pardon deforestation in a project full of controversies that pointed towards the regularization of many rural producers (from small riverside extractives to big agribusiness). 
The objective of the present work is to analyze how and in which degree the New Forests Code affects the special dynamics of the Landless Workers Movement Settlement, Roseli Nunes in Piraí where the PUC-Rio maintains exchange and research programs, and try to identify if the legislation changes benefited the collective of this Settlement or not, since they are supposed to be one of its target audience.

Key-words: Agrarian Reform, New Forests Code, Settlement Project Roseli Nunes 


\section{SUMÁRIO}

LISTA DE TABELAS E FIGURAS...............................................

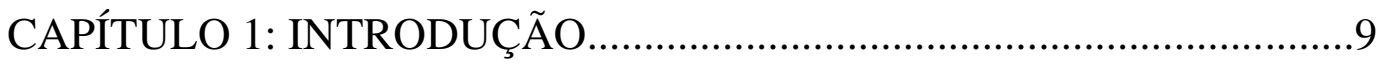

CAPÍTULO 2: DO NOVO “CÓDIGO FLORESTAL”...........................11

2.1 - Contexto social e político...................................................11

2.2 - O Processo legislativo...................................................... 13

2.3 - Alterações e novos dispositivos..........................................18

2.3.1 - Área Rural Consolidada (ARC) ........................................20

2.3.2 Reserva Legal (RL) ..................................................24

2.3.3 Cômputo das Áreas de Preservação Permanente na Reserva

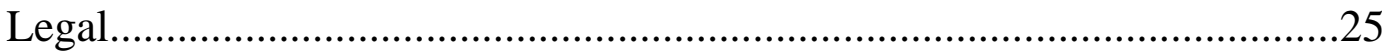

2.3.4 O Cadastro Ambiental Rural (CAR)............................................27

2.3.5 Mudanças técnicas nas APP's............................................28

2.3.6 Levantamento dos dispositivos pertinentes à análise de assentamentos rurais. .30

CAPÍTULO 3: DA REFORMA AGRÁRIA............................................31

3.1 - História.............................................................................. 31

3.2 Do processo de desapropriação............................................40

3.3 O MST e a reforma agrária: Perspectiva Nacional...................47

3.4: O MST e a reforma agrária no Rio de Janeiro.......................49

CAPÍTULO 4: ANÁLISE DO PROJETO DE ASSENTAMENTO ROSELI

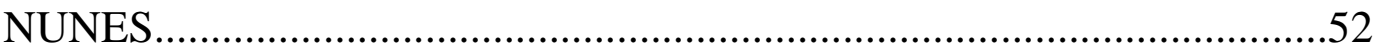

CAPÍTULO 5: CONCLUSÃO.........................................................6

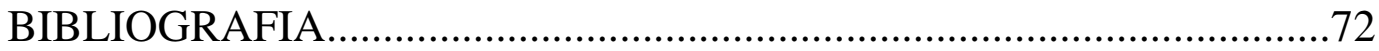




\section{LISTA DE TABELAS E FIGURAS}

TABELA 1: Extensão das APP's no regime padrão e nos diferentes regimes de Área Rural Consolidada.

TABELA 2: Projetos de reforma agrária e as regiões do Brasil .49

TABELA 3: Estrutura fundiária no município de Piraí. .51

TABELA 4: Produção proposta no Projeto de Assentamento .54

FIGURA 1 : Laudo de Vistoria e Avaliação (LVA) 60

FIGURA 2: Plano de Desenvolvimento do Assentamento - Ambiental...661

FIGURA 3: Plano de Desenvolvimento do Assentamento: Loteamentos.62

FIGURA 4: Ordenamento Territorial .64

FIGURA 5: Cadastro Ambiental Rural (CAR) .65 


\section{CAPÍTULO 1: INTRODUÇÃO}

A concentração de terra, o latifúndio, estão entre as maiores e mais antigas desigualdades históricas do Brasil. Todos os grandes processos políticos do país relacionam-se, de alguma forma, à questão agrária. Remontando a origem da palavra brasileiro aos extrativistas do Pau-Brasil, o Brasil construiu sua história com base em um modelo de agroexportação de produtos tropicais para os países centrais.

A pauta ambiental, apesar de ganhar crescente visibilidade, desde os anos 70, com o relatório Brundtland ("Nosso Futuro Comum") e os diversos encontros e acordos internacionais sobre o temática, como a Rio92, Johanesburgo $(+10)$ e Rio $+20^{1}$. No ordenamento jurídico brasileiro a temática ambiental já existia, sem entretanto ser assim abordada, de maneira orgânica e sem uma dogmática própria, mas antes abordada pontualmente, normalmente como maneira de regular a pressão antrópica sobre os ecossistemas, por exemplo: leis que regulavam a extração do PauBrasil, o reflorestamento forçado da Floresta da Tijuca como forma de manutenção da viabilidade da cidade do Rio de Janeiro.

Hoje, o cenário da degradação ambiental dos Biomas brasileiros é avançado: a Mata Atlântica com menos de $10 \%$ de sua área original ${ }^{2}$, o Cerrado com 50\% ${ }^{3}$, havendo em 2012 a aprovação do Novo Código Florestal que prometia regularizar a maior parte dos agricultores brasileiros (que se encontravam, em sua maioria, irregulares) com base em mudanças técnicas de definição das áreas protegidas, anistia à desmatadores etc. A justificativa retórica dos defensores do Novo Código era a descriminalização da pobreza, uma vez que o pequeno agricultor familiar

\footnotetext{
${ }^{1}$ Que estão as principais conferências internacionais sobre clima após a Conferência de Estocolmo (1972) sobre Meio Ambiente, onde foram gerados inúmeros documentos e acordos da temática ambiental, com exceção de Johanesburgo e da Rio+20, onde prevaleceu o ceticismo (ou a negação) em relação às mudanças climáticas.

${ }^{2}$ Disponível em: http://noticias.uol.com.br/meio-ambiente/ultimasnoticias/redacao/2013/06/04/restam-85-da-vegetacao-original-da-mata-atlantica-dizlevantamento.htma data de 09/06/2015 ${ }^{3}$ http://www.portalmodulo.com.br/userfiles/Amea\%C3\%A7a\%20ao\%20Cerrado\%20se\%20volta\% 20para\%20o\%20norte.pdf , acessado em 09/06/2015
} 
não poderia arcar com todos os prejuízos (não só financeiros) de uma aplicação dura da Lei anterior.

A presente investigação visa averiguar como as mudanças na legislação ambiental com o advento da Lei $n^{\circ} 12.651 / 12$ vieram a alterar as dinâmicas sócio-espaciais dos pequenos produtores rurais assentados da reforma agrária em um estudo de caso desenvolvido no Projeto de Assentamento Roseli Nunes, no Município de Piraí, na região sul do Estado do Rio de Janeiro, tanto como forma de auxiliar os assentados no desenvolvimento de suas atividades, quanto como meio de analisar os impactos reais do Novo Código Florestal, que de acordo com seus legisladores, regularizaria muitos agricultores.

O presente trabalho se baseia em visitas nas quais foram realizadas entrevistas semi-estruturadas com aproximadamente 10 técnicos de diferentes áreas das Seções de Obtenção e Desenvolvimento do INCRA RJ, ao longo de 7 visitas e comunicação constante, e com os próprios assentados do PA Roseli Nunes, realizadas durante duas vivências no local, além de palestras com outros conhecedores da reforma agrária e seus dispositivos institucionais e do levantamento, tanto de dispositivos legais pertinentes do direito ambiental (Código Florestal Novo e Antigo, Resoluções CONAMA, e suas aplicações pelo Judiciário) como do direito fundiário/agrário (Lei da Reforma Agrária - 8.629/93, Estatuto da Terra, e sua interpretação atual, súmulas etc) ambos em um viés Constitucional, como não poderia deixar de ser, para então analisar o processo de adequação do Assentamento objeto da pesquisa à nova normatividade instaurada pelo Novo Código Florestal de 2012. Paras tanto debruçou-se o autor sobre os documentos do processo de desapropriação, do Cadastro Ambiental Rural entre outros que revelam a progressividade temporal da formação do Assentamento Roseli.

Com base nos balanços destas investigações, pretende-se lançar um diagnóstico dos efeitos da nova legislação florestal sobre o ordenamento mas principalmente sobre a dinâmica do Assentamento Roseli Nunes e 
averiguar se veio a lhe beneficiar ou prejudicar, como forma de parâmetro para averiguação (produção de um balanço) da efetividade dos dispositivos legais do Novo Código Florestal na regularização da situação dos pequenos agricultores brasileiros (parte do público-alvo desta política pública).

\section{CAPÍTULO 2: DO NOVO CÓDIGO FLORESTAL (NCF)}

\section{1: Contexto social e político}

O Brasil ocupa um lugar muito estratégico no processo produtivo internacional. Infelizmente, como é de conhecimento geral, esse lugar é o de fornecimento de matérias-primas brutas, isto é, não manufaturadas, sem valor agregado, comercializadas internacionalmente nas bolsas de valores em grande quantidade por preços baixos, também conhecidas como commodities. A agricultura no Brasil se desenvolveu, desde a ocupação portuguesa, de maneira predatória (por não respeitar os ecossistemas locais, retirando dele mais serviços ecossistêmicos do que os disponíveis, acarretando sua supressão), monocultural (grandes extensões de terra com um só cultivo) e acumuladora, já que todos os grandes ciclos de cultivo eram voltados para comercialização nos mercados internacionais ${ }^{4}$, de maneira que a terra não era cultivada visando maior autonomia dos colonos, mas maior lucro, cultura denominada internacionalmente como "cash crop" ("cultivo de grana"). Tal desenvolvimento produz uma estrutura fundiária extremamente concentradora, uma vez que o escoamento dos produtos é definido por uma demanda estrangeira e o lucro está condicionado à produção de grandes quantidades, por causa dos preços baixos, prospera aquele que tem mais terra para produzir.

Hoje, o Brasil é o $2^{\circ}$ maior exportador de soja transgênica do mundo, o maior mercado interno de agrotóxicos. Apesar da vultuosa produção para

\footnotetext{
${ }^{4}$ Programa Agrário do MST para o período 2014-2019. Pág. 11.
} 
exportação pelo agronegócio (que, de fato, contribui para o equilíbrio da balança comercial, representando $23,3 \%$ do $\mathrm{PIB}^{5}$ ), $70 \%$ de todo o alimento ingerido pela população do país é produzido por pequenos produtores rurais.

Devemos lembrar entretanto que há grande variação do perfil dos pequenos produtores no Brasil, não constituindo este uma coletividade homogênea: há a pequena agricultura familiar empresarial, a campesina, a cooperativa etc, com maior incidência em diferentes regiões do país. Este grupo, apesar de suas diferenças, é o que mais comumente enfrenta óbices econômicos e políticos, uma vez que tem menos acesso a crédito e terra, e menos projeção política que os latifundiários (tradicionais ou corporativos), apesar de empregar mais mão-de-obra ${ }^{6}$ e cumprir papel mais relevante que o agronegócio no abastecimento nacional ${ }^{7}$.

O quadro é agravado por balizas legais: já constrangido pela falta de acesso à terra e crédito o pequeno agricultor se vê apertado ainda pelas proteções jurídicas ambientais reduzem ainda mais o espaço disponível para cultivos.

Pressionados por todos os lados (economicamente, politicamente, ambientalmente), muitos agricultores se viram compelidos a adentrarem, seja por ignorância, seja por má-fé, os espaços territoriais especialmente protegidos de suas propriedades, a saber, as Áreas de Preservação Permanentes (APP's) e as Reservas Legais (RL's). Dentro deste quadro, muitos produtores estavam de fato irregulares, o que ainda aumentava sua já acentuada vulnerabilidade socio-economica. Foi com a retórica de objetivar regularizar a situação descrita que o Deputado Federal Aldo Rebello (PC do B, Alagoas) colocou na pauta do dia o PL 1876/1999.

\footnotetext{
${ }^{5}$ Em 2014: http://www.canaldoprodutor.com.br/comunicacao/noticias/pib-do-agronegocio-cresce38-em-2014, acessado em 12/05/2015

${ }^{6}$ De acordo com a Conab, a agricultura familiar responde por sete em cada dez empregos no campo: http://www.conab.gov.br/conteudos.php?a=1125,

${ }^{7} 70 \%$ da alimentação nacional (não exportação): http://www.contag.org.br/index.php?modulo=portal\&acao=interna\&codpag=263\&nw=1, acessado em: 09/05/2015
} 


\section{2: O Processo legislativo: Análise do Relatório 1876/1999}

Em 25 de maio de 2012 foi sancionado o Novo Código Florestal brasileiro. Fruto de um processo legislativo que se desenrolava desde 1999, com a apresentação na Câmara dos Deputados, pelo deputado Sérgio Carvalho (PSDB - RO), de Projeto de Lei que propunha a alteração do Código Florestal de 1965, mas que ganhou novo fôlego em 2010, sob a relatoria do deputado Aldo Rebelo (PCdoB - AL). Comemorado pelo Agronegócio $^{8}$ e criticado por amplos setores da sociedade civil ${ }^{9}$ : desde O.N.G.'s ambientais como Green Peace, W.W.F., S.O.S. Mata Atlântica, até movimentos sociais de caráter laboral/sindical, tais como a Central Única dos Trabalhadores (CUT), Via Campesina, OAB (que pleiteou a inconstitucionalidade de dispositivos do diploma), organizações científicas como a $\mathrm{SBPC}^{10}$ além de diversas personalidades públicas, políticos e acadêmicos como o geógrafo Aziz Ab-Saber e a ex-senadora Marina Silva ${ }^{11}$, o Novo Código se amparou em uma retórica de regularização da situação ilegal dos agricultores do país, que de acordo com dados disponíveis à época chegavam a 90\% destes.

A retórica empregada pelo Deputado Aldo Rebelo em seu Relatório sobre o PL 1876/1999 ${ }^{12}$ se divide em alguns estratagemas: primeiramente, conceitua o ambientalismo como sendo amplamente um movimento elitista, o movimento anti-antropocêntrico como antrofóbico, em especial no caso

\footnotetext{
${ }^{8}$ Senadora Kátia Abreu comemora aprovação do Código: https://www.google.com.br/url?sa=t\&rct=j\&q=\&esrc=s\&source=web\&cd=1\&cad=rja\&uact=8\&v ed=0CB0QFjAA\&url=http\%3A\%2F\%2Fsenadorakatiaabreu.com.br\%2F\%3Fp\%3D1695\%26cpag e\%3D1\&ei=1Uo0VZ2JFfK sQTQyoEg\&usg=AFQjCNEp1R82b2q7IWNG48mNe2uWIS1_ig\&bv $\mathrm{m}=$ bv.91071109,d.cWc, acessado em 09/06/2015.

9 Nota pública do Green Peace sobre o NCF: http://www.greenpeace.org/brasil/pt/Documentos/Nota-publica-sobre-o-novo-Codigo-FlorestalBrasileiro/ acessado em 09/06/2015.

${ }^{10}$ Sociedade Brasileira para o Progresso da Ciência. A organização emitiu

${ }^{11}$ Aziz Ab'Sáber faz duras críticas ao Novo Código Florestal: http://ultimosegundo.ig.com.br/ciencia/aziz+absaber+faz+duras+criticas+ao+novo+codigo+florest al/n1237730056382.html, acessado em 09/06/2015.

$12 \quad$ Disponível em http://www.camara.gov.br/proposicoesWeb/fichadetramitacao?idProposicao=17338, acessado em 09/06/2015.
} 
da pobreza, que se torna alvo de tutela da coletividade, principalmente no que toca o quesito padrão de consumo, controle de natalidade etc, onde travestem-se de políticas pró-sociais políticas de vigilância e controle das populações menos abastadas: uma vez que estruturalmente a cidadania e seus direitos, são no estado de direito burguês, privilégios progressivos das classes mais abastadas. Como desdobramento desta retórica do ambientalismo como política de classes dominantes suplantando as liberdades e capacidades das classes mais baixas, o Deputado cita, sem entretanto nomeá-la, a tese das "Responsabilidades comuns mas diferenciadas", princípio expresso na Declaração do Rio sobre Meio Ambiente e Desenvolvimento ${ }^{13}$ ratificado pelo Brasil durante a Conferência Rio 92, no qual entende-se que os países em desenvolvimento teriam o direito de emitirem mais gases e poluentes em um processo de industrialização e aquecimento das suas economias que permitam a estes países alcançarem os patamares financeiros, sociais e econômicos dos países desenvolvidos, que ainda de acordo com a teoria, seriam os principais atores responsáveis pela Revolução Industrial, pelos poluentes por ela emitidos e danos ambientais produzidos, e que são portanto, responsáveis primários, além de maiores beneficiários do estado de degradação ambiental global de hoje.

Para ilustrar seu pensamento, o Deputado apresenta o debate Malthusiano acerca dos limites demográficos do planeta, e como a mesma retórica foi empregada por movimentos elitistas tais como o "Clube de Roma" e sua famosa publicação "Os Limites do Crescimento", que o deputado, aponta atualizador do pensamento de Malthus, apontando nisto uma tentativa dos mais desenvolvidos de solaparem o crescimento dos menos desenvolvidos por meio de uma retórica de proteção ambiental correlacionada a um desaquecimento econômico. Lembra o deputado, versando Josué de Castro em lição na qual ataca a teoria Malthusiana, que a superpopulação não era causa da fome, mas que a fome fazia com que os

\footnotetext{
${ }^{13}$ Disponível em: http://www.onu.org.br/rio20/img/2012/01/rio92.pdf, acessado em 09/06/2015
} 
pobres tivessem na multiplicação de seus filhos a esperança de ajudá-los na sobrevivência e braços para o trabalho.

Um ponto relevante da retórica do Deputado Aldo Rebelo é cognição acerca da relação homem-natureza. Postulando uma semi-ótica de conflito, o Deputado visa combater uma suposta visão romântica desta relação, em especial no que toca a agricultura. Podemos ler em seu parecer sobre o PL 1876:

A conquista de qualquer tipo de terra pela colonização é sempre o resultado de uma luta lenta e tenaz entre o homem e os obstáculos do meio geográfico. Entre a força criadora do elemento humano e as resistências dos fatores naturais. $\mathrm{Na}$ paisagem virgem, o homem é sempre um intruso que só se pode manter pela força. O geógrafo francês Pierre Déffontaines, tratando da dinâmica da colonização, dos ajustamentos dos grupos humanos aos diferentes quadros naturais, fala-nos sempre em lutas. Em luta do homem contra a montanha. Em luta do homem contra a água. Em luta do homem contra a floresta.

De fato, a expansão agrícola inclui processos de conflito, subjugação e dominação. Mas esta é também a cognição hegemônica agrícola atual, e principalmente no Brasil. Resulta de uma visão, pode se dizer eurocêntrica/logocêntrica, de instrumentalização da natureza dos outros seres, sem dar a eles o "privilégio" (nesse caso como construção social humana) da inteligência, da sentiência. Esta violência do processo de adaptação da agricultura, resulta menos da expansão do próprio homem e mais dos processos e técnicas empregados por humanos para se adaptarem. Em leitura diametralmente oposta à do Deputado cito o mesmo dizer de Josué Castro em "A Geografia da Fome" citado pelo deputado no PL 1876:

Para melhorar as condições alimentares da área amazônica faz-se necessário todo um programa de transformações econômico-sociais na região. As soluções dos aspectos parciais do problema estão todas ligadas à solução geral de um método de colonização adequado à região. Sem alimentação suficiente e correta a Amazônia será sempre um deserto demográfico. Sem um plano de povoamento racional e de fixação colonizadora do elemento humano à terra nunca se poderá melhorar os recursos da alimentação regional.

Podemos concluir da leitura deste trecho que os problemas da ocupação estão relacionados à adequação do método empregado à região. Ora, introduzir uma agricultura monocultural, ou mesmo diversificada mas de matriz exótica, em um ecossistema como o Amazônico, ainda aliado a 
hábitos alimentares e culturais importados de baixa adaptabilidade ecossistêmica (como a ingestão de trigo ser base da alimentação na maioria das regiões do Brasil, onde não se produz trigo, sendo a única região produtora o Sul), não se pode culpar a floresta e a natureza pelos sofrimentos do homem, mas este mesmo pelas suas técnicas e hábitos (modos de ser e fazer - cultura). A adaptabilidade ecossistêmica é princípio básico da Agroecologia, servindo o Programa Nacional (de Agroecologia) como balizador e norteador desta pesquisa quanto a um modelo sustentável de produção e conservação, que leva em conta uma adaptação de técnicas ao ecossistema local ou mesmo a criação de novas técnicas e o abandono de outras.

Ao defender esta posição, apesar da necessidade de apoio aos agricultores, principalmente os pequenos e mais carentes/hipossuficientes, que mais precisam de políticas públicas, o Deputado se torna omisso, uma vez que oculta a responsabilidade dos próprios agricultores e do emprego de suas técnicas de baixa adaptabilidade ecossistêmica, demonizando outras instâncias, tais como ONG's, os órgãos de fiscalização e controle, transferindo as responsabilidades daqueles primeiros, romantizando a imagem dos agricultores de uma maneira geral como guerreiros incansáveis, sem tocar nos defeitos e problemas que lhes são próprios, e sem tocar a problemática das práticas e modelos agriculturais, encarando a questão sob um prisma individual (focando na resolução de problemas proprietários) e menos estrutural, isto é, a questão do modelo de produção, consumo, distribuição sócio-espacial. Podemos inclusive afirmar que optouse por reforçar um modelo de proteção abstrato ${ }^{14}$.

Seguindo essa linha de raciocínio, o deputado Aldo Rebelo, prossegue, ilustrando seu pensamento com os exemplos do Porto de Santos, das barreiras do Rio Madeira e de transposição do São Francisco, como sendo casos de impactos ambientais nos quais é válido o trade off, entre os

\footnotetext{
${ }^{14}$ Muito criticado por Aziz Ab'Saber em sua carta pública "Do Código Florestal ao Código da Biodiversidade"
} 
bens ambientais e os benefícios econômicos e sociais, e que devem prosseguir mesmo com forte resistência de muitos setores. Ao dizê-lo, representando direitos de muitos cidadãos à uma sociedade mais justa e fraterna, ao trabalho e à condições de vida dignas, nosso ilustre deputado se esquece que sacrifica o direito de outras coltividades para atender à outras. Como é o caso dos pescadores que não mais poderão tirar sua subsistência depois da poluição do Porto de Santos, ou no caso de Belo Monte, onde são violados sistematicamente direitos dos povos tradicionais e ribeirinhos da região onde está sendo construída a barreira. Importante aqui é frisar a retórica do "progresso", "do "avanço", propugnada pelo parlamentar, instaurando uma hierarquia temporal entre sociedades, a temporalização da diferença e uma ideia de progressividade temporal, ou seja de evolução histórica.

Vale ressaltar o papel da Frente Parlamentar da Agropecuária ${ }^{15}$ no processo de aprovação do Código. Constituída por políticos de diversas legendas partidárias, mas sob a liderança e com maioria esmagadora de parlamentares do PMDB, tendo 50 deputados e 5 senadores ${ }^{16}$ dentre o total de 188 deputados e 22 senadores, totalizando 210 parlamentares federais, somente. Defensora de causas como o abrandamento da tipificação do trabalho escravo ${ }^{17}$, em favor dos $\operatorname{agrotóxicos}^{18}$, dos organismos geneticamente modificados (OGM's) ${ }^{19}$, da agilização (e precarização) dos procedimentos de liberação comercial e redução das exigências de

\footnotetext{
${ }^{15}$ Que, inclusive, conta com website próprio, disponível em: http://fpagropecuaria.org.br/ ${ }^{16}$ seguidos de PP: 18/4 ; PSDB: 17/3; PR: 16/3; PSD: 15/2; DEM: 12/1; SD 12/0; PDT 10/1; PTB 9/0; PSB 9/0; PT: 7/0; PRB: 6/0; PSC: 4/1; PROS 5/0; PPS: 2/2; PHS: 2/0; PV: 2/0; PMN: 1/0; PEN: $1 / 0$, com dados coletados na página oficial da Frente Parlamentar da Agropecuária na internet (http://fpagropecuaria.org.br/composicao) pelo próprio autor em 10/04/2015)

${ }^{17}$ Trabalho escravo. Comissão de Agricultura aprova parecer do deputado Heinze:

http://fpagropecuaria.org.br/noticias/trabalho-escravo-comissao-de-agricultura-aprova-parecer-dodeputado-heinze\#.VTR5BNxViko acessado em 09/06/2015

${ }^{18}$ Agrotóxicos. Encontro quer provar que não faz mal à saúde: http://fpagropecuaria.org.br/noticias/agrotoxicos-encontro-quer-provar-que-nao-faz-mal-asaude\#.VTR7GtxViko acessado em 09/06/2015

19 Biotecnologia sob ameaça, disponível em: http://fpagropecuaria.org.br/artigos/biotecnologiasob-ameaca\#.VTSVOtxViko acessado em 09/06/2015
} 
rotulagem destes, da PEC $215^{20}$, criticada por muitos juristas e setores da sociedade civil, que retira as competências para demarcação das Terras Indígenas, Quilombolas e Unidades de Conservação do Poder Executivo Federal, concentrando-as no Congresso Nacional, esta Frente Parlamentar cumpre hoje a representação da classe patronal do agronegócio.

\section{3: Alterações e novos dispositivos}

O "Novo Código Florestal"21 (NCF), Lei 12.651 de maio de 2012, teve muitos de seus dispositivos alterados pela Lei 12.727 que veio no mês de outubro do mesmo ano, dando nova redação a estes.

$\mathrm{O}$ NCF trouxe muitas inovações desde a introdução do regime das Áreas Rurais Consolidadas (ARC), que pode ser descrita como política de anistia ambiental aos imóveis rurais em situação irregular, alterações no regime das Áreas de Preservação Permanente (APP's), principalmente quando nelas houverem ocupações humanas pré-existentes a 22 de julho de 2008, assim como também altera-se o regime das Reservas Legais (RL's) nestas ARC's.

Há toda uma sistematização no NCF prevendo a utilização do Cadastro Ambiental Rural (CAR), sendo obrigatório, até como forma de incentivo a regularização tanto ambiental, quanto cadastral, de atualização junto às instâncias governamentais de controle. O CAR usualmente envolve processos de georeferenciamento e outros estudos, que permitem ao agricultor aumentar seu conhecimento acerca das possibilidades do imóvel, uma vez que também, há a eliminação das dúvidas referentes à localização

\footnotetext{
${ }^{20}$ Ruralistas pedem reabertura de comissão da PEC 215, disponível em: http://fpagropecuaria.org.br/noticias/ruralistas-pedem-reabertura-de-comissao-da-pec215\#.VTSXfdxViko acessado em 09/06/2015

${ }^{21}$ Alguns autores tem utilizado aspas para se referir à Lei 12651/12 como Código Florestal: pontuam que, na realidade, se trata de um código agrário-florestal, por se utilizar de muitos conceitos do ramo de direito agrário como os módulos fiscais, além de obrigar a adequação das irregularidades ambientais com base na área do imóvel.
} 
das áreas protegidas, quando de sua averbação definitiva junto aos órgãos ambientais competentes.

Outro ponto importante de frisar é que o NCF se baseia em conceitos de direito agrário, revelando uma opção de incutir em seu conteúdo, caráter de condução de um modelo de desenvolvimento agrário, optando por uma suposta neutralidade em relação à grande concentração de terra, que como veremos terá tratamento diferenciado e muitas vezes permissivo, estendendo anistia a proprietários abastados, cuja ilicitude, ao contrário do argumento utilizado por Aldo Rebelo, não acarretaria em prisões ou comprometimento da vida e das condições da própria subsistência, mas na mera redução dos lucros, por internalizar no balanço comercial o passivo ambiental oriundo da atividade irregular. Isto se torna mais flagrante à medida que identificamos no NCF, o uso de conceitos como módulos fiscais.

O conceito de módulos fiscais hoje, além de incidir em questões tributárias, para fim de avaliação dos tributos reais aplicáveis, também tem diversos outros desdobramentos. Como pode se averiguar é com a aplicação deste conceito (de módulo fiscal) que se define legalmente, no artigo $3^{\circ}$ da Lei 12.326 de 2006 (que estabelece o Programa Nacional de Agricultura Familiar e Empreendimentos Familiares Rurais), o que é a agricultura familiar:

Art. 3o Para os efeitos desta Lei, considera-se agricultor familiar e empreendedor familiar rural aquele que pratica atividades no meio rural, atendendo, simultaneamente, aos seguintes requisitos:

I - não detenha, a qualquer título, área maior do que 4 (quatro) módulos fiscais;

II - utilize predominantemente mão-de-obra da própria família nas atividades econômicas do seu estabelecimento ou empreendimento;

III - tenha renda familiar predominantemente originada de atividades econômicas vinculadas ao próprio estabelecimento ou empreendimento;

III - tenha percentual mínimo da renda familiar originada de atividades econômicas do seu estabelecimento ou empreendimento, na forma definida pelo Poder Executivo; (Redação dada pela Lei $n^{\circ} 12.512$, de 2011)

IV - dirija seu estabelecimento ou empreendimento com sua família.

Aqueles que se adequarem a esta definição poderão então usufruir dos créditos, seguros, assistência técnica e demais serviços da Política Nacional de Agricultura Familiar e Empreendimentos Familiares Rurais. 
São equiparáveis aos produtores do artigo $3^{\circ}$ os silvicultores, aquicultores, populações remanescentes de quilombolas, pescadores, extrativistas e povos indígenas (Lei 12.326, artigo $3^{\circ}, \S 2^{\circ}$ ).

De acordo com a Empresa Brasileira de Pesquisa Agropecuária (EMBRAPA), o conceito de módulo fiscal significa:

\begin{abstract}
Módulo Fiscal (MF) é uma unidade de medida agrária que representa a área mínima necessária para as propriedades rurais poderem ser consideradas economicamente viáveis (BRASIL, 2012a). Foi instituída pela Lei n ${ }^{\circ} 6.746$, de 10 de dezembro de 1979. O tamanho do módulo fiscal varia de 5 a 110 hectares, conforme o município. O tamanho dos módulos fiscais foi fixado inicialmente pela Instrução Especial no 20, de 1980, do INCRA (BRASIL, 1980). Municípios criados posteriormente tiveram o tamanho do módulo fiscal fixado por Portarias e Instruções Especiais mais recentes. Foi o caso das Instruções Especiais no 541, de 1997, e no 3 de 2005, para municípios instalados em 1997 e 2005, respectivamente (BRASIL, 1997, 2005). ${ }^{22}$
\end{abstract}

Para quantificação de módulos fiscais, irá se utilizar de informações tais como: a exploração predominante do solo na região, a renda obtida com essa exploração, além de outras explorações não-predominantes mas expressivas na geração de renda e da utilização do modelo familiar de produção no local e como se estrutura. Vale lembrar que a medida padrão do hectare (medida na qual se assenta o módulo fiscal) é de $10.000 \mathrm{~m}^{2}$ (dez mil metros quadrados).

\title{
2.3.1: Área Rural Consolidada (ARC)
}

Entre as principais mudanças do Código Florestal pode se listar a introdução do regime de Área Rural Consolidada, que são definidas na redação do próprio diploma como:

área de imóvel rural com ocupação antrópica preexistente a 22 de julho de 2008 , com edificações, benfeitorias ou atividades agrossilvipastoris, admitida, neste último caso, a adoção do regime de pousio

Isto significa que as propriedades que não respeitavam o Código Florestal até 22 de julho de 2008 e mantinham edificações, benfeitorias ou

\footnotetext{
${ }^{22}$ LANDAU, Helena Charlotte et alii. Variação Geográfica do Tamanho dos Módulos Fiscais no Brasil. EMBRAPA Documentos 146, Novembro, 2012.
} 
atividades agrossilvipastoris em áreas superiores às permitidas pela Legislação à época ganharam alternativas à obrigação de recompor a área in situ, estando o proprietário desincumbido de pagar a multa pelo ilícito ambiental por meio de compensações estabelecidas no próprio Código.

No caput do artigo 15 do NCF há a permissão legal para que os proprietários dos imóveis (cadastrados no Cadastro Rural Ambiental CRA) cuja área da RL ultrapasse o mínimo exigido em lei se utilizem deste excedente para constituir Cotas de Reserva Ambiental, que são definidas em lei como "título nominativo representativo de área com vegetação nativa, existente ou em processo de recuperação". Estas Cotas (que também são servidões ambientais submetidas ao regime estabelecido nos artigos $9^{\circ}$, $9^{\circ} \mathrm{A}, 9^{\circ} \mathrm{B}$ e $9^{\circ} \mathrm{C}$ da Política Ambiental do Meio Ambiente - Lei 6938/81) podem ser adquiridas como forma de compensação ambiental (inciso I do $\S 5^{\circ}$, artigo 66, Lei 12651)para a regularização da situação dos imóveis cujas as áreas das RL's estejam em extensões menores que as legais (Lei 12.651, art. 66 caput e inciso III). O problema deste instituto é que ao permitir a compensação das RL's dos imóveis em outros locais $\left(\S 6^{\circ}\right.$, artigo 66 , Lei 12651) a Lei regulariza (principalmente se observado os casos de grandes extensões de terra particular desmatada) a degradação ambiental resultante da não restauração dos processos ecossistêmicos (inc. I, §1 ${ }^{\circ}$, art. 225, C.F.), causa uma descontinuidade ecossistêmica no local, que impossibilitará um livre deslocamento da fauna e flora -o que caracteriza uma falha em sua proteção (que tem origem constitucional: inc. VI, $\S 1^{\circ}$, art. 225 , C.F.),esta desfragmentação ecossistêmica leva à perda da biodiversidade local e da integridade do patrimônio genético (inc. II $\S 1^{\circ}$, art. 225, C.F.) protegendo uma propriedade que não cumpre sua função socioambiental, insistindo em um modelo de conservação formalista, insensível à situações espaciais específicas, às espécies endêmicas, fluxos migratórios e outros processos ecológicos de maior ou menor escala, e portanto, violando direitos constitucionais. 
TABELA 1: Extensão das APP's no regime padrão e nos diferentes regimes de ARC

\begin{tabular}{|c|c|c|c|c|c|}
\hline & $\begin{array}{l}\text { Proteção } \\
\text { padrão }\end{array}$ & $\begin{array}{l}\text { Regime } \\
\text { ARC - } \\
\text { até } \quad 1 \\
\text { módulo } \\
\text { fiscal }\end{array}$ & $\begin{array}{l}\text { Regime } \\
\text { ARC - de } \\
1 \quad \text { a } 2 \\
\text { módulos } \\
\text { fiscais }\end{array}$ & $\begin{array}{l}\text { Regime } \\
\text { ARC -de } \\
2 \quad \text { a } 4 \\
\text { módulos } \\
\text { fiscais }\end{array}$ & $\begin{array}{lr}\text { Regime } \\
\text { ARC - mais } \\
\text { de } \\
\text { módulos } \\
\text { fiscais }\end{array}$ \\
\hline $\begin{array}{l}\text { Cursos } \\
\text { d'água } \\
\text { naturais, } \\
\text { perenes e } \\
\text { intermitentes }\end{array}$ & $\begin{array}{l}\text { Mínima: } \\
\text { 30m } \\
\text { Máxima: } \\
\text { 600m }\end{array}$ & $5 \mathrm{~m}$ & $8 \mathrm{~m}$ & $15 \mathrm{~m}$ & $\begin{array}{l}\text { Varia } \\
\text { conforme } \\
\text { determinação } \\
\text { do PSA. } \\
\text { Mínima: } \\
20 \mathrm{~m} \\
\text { Máxima: } \\
100 \mathrm{~m}\end{array}$ \\
\hline $\begin{array}{l}\text { Fontes } \mathrm{e} \\
\text { olhos d'água } \\
\text { perenes }\end{array}$ & $50 \mathrm{~m}$ & $15 \mathrm{~m}$ & $15 \mathrm{~m}$ & $15 \mathrm{~m}$ & $15 \mathrm{~m}$ \\
\hline $\begin{array}{l}\text { Lagos } \\
\text { Lagoas } \\
\text { naturais em } \\
\text { zona rural }\end{array}$ & $\begin{array}{l}\text { De } 50 \text { a } \\
100 m\end{array}$ & $5 \mathrm{~m}$ & $8 \mathrm{~m}$ & $15 \mathrm{~m}$ & $30 \mathrm{~m}$ \\
\hline Veredas & $50 \mathrm{~m}$ & $30 \mathrm{~m}$ & $30 \mathrm{~m}$ & $30 \mathrm{~m}$ & $50 \mathrm{~m}$ \\
\hline
\end{tabular}

*Tabela elaborada pelo próprio autor.

Há de se indagar se o instituto das ARC do NCF, no que contemplou os pequenos proprietários que estruturam familiarmente sua produção, acertou no quesito de anistiar aqueles que incorreram em ilícitos ambientais por ignorância das normais legais ou por força da necessidade, para a própria subsistência, combatendo a criminalização e marginalização dos pequenos produtores, na sua maioria inocentes que, afinal, também 
contribuem para uma economia popular complexa. Entretanto, ao basear-se em conceitos fundiários, supostamente neutros, como no caso das definições por módulo fiscal, o legislador optou por estender esta "anistia" aos grandes proprietários, não agindo de forma afirmativa na questão do desenvolvimento agrário, no reforço de um modelo de produção historicamente desprivilegiado, como foi a pequena produção familiar, desprivilegiando com isto, também, a pauta da reforma agrária.

Apesar da retórica pró-social, de desmarginalização da pobreza, o abrandamento da recomposição de certas APP's como no caso das matas ciliares em cursos d'água naturais, pode ocasionar uma séria perda da função ecológica destas matas. Em prol de uma maior liberdade (relativa ao uso da propriedade) ou segurança (jurídica, principalmente se pensarmos nos grandes exportadores), abre-se mão da função ecológica de parte de um determinado ecossistema, o que reduz não só sua capacidade de regeneração como a salubridade do ambiente, que é um direito fundamental difuso (C.F., artigo 225 caput), restando a coletivação do ônus do dano ambiental e a privatização de seus benefícios (pelo proprietário anistiado).

Outro ponto muito controverso que aponta o favorecimento dos latifúndios no NCF é a não-estipulação fixa da faixa de recomposição obrigatória no caso das APP's em cursos d'água em imóveis com área superior à 4 módulos fiscais, mas sua estipulação ad hoc pelo Programa de Regularização Ambiental (PRA), sem definição legal de critérios para tanto, o que além de criar uma insegurança jurídica pelo grau de subjetividade dado aos fiscais do PRA e diminuindo bruscamente a responsabilidade dos grandes produtores, que tem a obrigação de recomposição reduzida à um mínimo de 20m (10 a menos que o padrão mínimo de 30m) e um máximo de $100 \mathrm{~m}$ (400m a menos que o padrão máximo de 500m). Se imaginarmos um imóvel de mais de quatro módulos fiscais, situado às margens de um rio com largura superior a 600 metros, cuja APP de mata ciliar deveria se estender por $500 \mathrm{~m}$ a partir da borda da calha do leito regular. Caso essa mata tenha sido suprimida e nela realizada alguma das atividades descritas 
como consolidadoras de área rural (inciso IV, artigo $3^{\circ}, \mathrm{NCF}$ ), o proprietário só deverá recompor, no máximo, 100m. Isto é, houve um ganho de 400m de "área útil" do imóvel. Parece um bom negócio ter desmatado até 22 de julho de 2008. Em relação a isto, pode-se ainda propor a discussão do privilégio aos agricultores irregulares, colocando estes em posição mais vantajosa que os regulares, por agora disporem de maior área de uso em sua propriedade, desequilibrando a concorrência a favor da ilicitude, o que além de parecer tratamento discriminado entre brasileiros, e portanto inconstitucional (, se revela uma má estratégia para a construção de um mercado equilibrado e cidadão. Este é um dos pontos onde o NCF foi mais permissivo, e ao sê-lo está anuindo com a perda de parte relevante das funções ecológicas da mata ciliar, que contribuem, pelo efeito de acúmulo, para o abastecimento de corpos hídricos maiores ${ }^{23}$.

\subsection{2: Reserva Legal (RL)}

Prevista de forma geral no artigo 12 da Lei $n^{\circ} 12.651$, que estabelece o mínimo percentual da área do imóvel a ser conservado a título de Reserva Legal, de acordo com a região do país na qual se localiza o imóvel, podendo variar de $20 \%$ a $80 \%$ da área total do imóvel. Entretanto, a mesma Lei previu uma hipótese de flexibilização desta proteção mínima. Quando aplicado à área de Reserva Legal o conceito de Área Rural Consolidada, o NCF previu um regime especial para as propriedades com até 4 módulos fiscais:

Art. 67. Nos imóveis rurais que detinham, em 22 de julho de 2008, área de até 4 (quatro) módulos fiscais e que possuam remanescente de vegetação nativa em percentuais inferiores ao previsto no art. 12, a Reserva Legal será constituída com a área ocupada com a vegetação nativa existente em 22 de julho de 2008, vedadas novas conversões para uso alternativo do solo.

\footnotetext{
23 Isto porque há por estudiosos como Aziz Ab'Saber, a demanda de um Código da Biodiversidade, estando o modelo de proteção genérica e abstrato, também comprometido por imprecisão. Há em sua Carta também a crítica à concepção de pequena propriedade poder abarcar, em alguns Municípios da Federação, até 440 hectares, o que decorre de um modelo centralizador e abstrativo de gestão do território, levando às presentes distorções.
} 
Há também, previsão do regime de Reserva Legal a ser adotado quando do fracionamento do imóvel, inclusive aqueles destinados à Assentamentos de Reforma Agrária, no $\S 1^{\circ}$ do artigo 12 do NCF:

$\S 1$ Em caso de fracionamento do imóvel rural, a qualquer título, inclusive para assentamentos pelo Programa de Reforma Agrária, será considerada, para fins do disposto do caput, a área do imóvel antes do fracionamento.

Ou seja, nos imóveis de até 4 módulos fiscais que tiverem desmatado sua Reserva Legal, será considerada como tal vegetação nativa existente a data de 22 de julho de 2008. Se inferior ao mínimo legal ou mesmo não havendo esta vegetação, fica o proprietário isento da recomposição da RL aos padrões mínimos legais. Por um lado, regulariza muitos pequenos produtores, combatendo a punição da pobreza, uma vez que o artigo 67 do NCF confere essa garantia aos pequenos proprietários, mas por outro lado, ao assumir postura demasiado permissiva, acaba por descaracterizar as funções ecológicas que a proteção legal visava efetivar.

\subsection{3: Cômputo das Áreas de Preservação Permanente na Reserva Legal}

No antigo Código Florestal de 1965, podíamos encontrar no parágrafo sexto do artigo 16 deste diploma, a previsão do cômputo das Áreas de Preservação Permanente no cálculo do percentual de Reserva Legal de um imóvel. Neste, era previsto que o cômputo só seria possível quando as áreas de matas nativas das APP's somadas à RL excedessem a $50 \%$ do tamanho total da propriedade rural (com exceções aos casos de pequena propriedade rural ou posse rural familiar, no qual este mínimo é de 25\% da área do imóvel e de $80 \%$ nos casos de imóveis situados em área de Amazônia Legal). Quando contrastado com antiga previsão mínima de área de Reserva Legal, que de acordo com o caput do citado artigo 16 estabelecia como regra geral o mínimo de $20 \%$ do imóvel como área de RL (este mínimo aumentava para 35\% nos casos de propriedade localizada no bioma cerrado dentro da Amazônia Legal e de 80\% nos casos de 
propriedade em floresta da Amazônia Legal). Isto quer dizer que as APP's só poderiam ser computadas no percentual de Reserva Legal se estas ultrapassassem os mínimos exigidos da Reserva Legal. Com isto, a proteção das APP's, quando estas excedessem o exigido pelo parágrafo sexto do artigo 16 da Lei 4771, por si só exoneraria o proprietário de manter outras coberturas vegetais à título de RL por já ter atendido uma função ambiental de sua propriedade.

No caso da pequena propriedade ou posse familiar, haveria com a conservação somente de APP superior ao mínimo exigido para o cômputo em percentual de RL, um acréscimo (mínimo) de 5\% em relação à proteção básica da RL. Este acréscimo pode chegar a um mínimo de 30\% nos casos de outras propriedades em geral. Já nas propriedades localizadas em Amazônia Legal há uma equivalência entre o mínimo percentual de APP computável e o mínimo de RL. Outra condição do cômputo era que este não fosse feito para conversão de novas áreas para uso alternativo (que não o de proteção ambiental), condição esta mantida no Novo Código. Vejamos a diferença de redações:

$\S 6^{\circ}$ [do artigo 16 do Código Florestal de 1965]: Será admitido, pelo órgão ambiental competente, o cômputo das áreas relativas à vegetação nativa existente em área de preservação permanente no cálculo do percentual de reserva legal, desde que não implique em conversão de novas áreas para o uso alternativo do solo, e quando a soma da vegetação nativa em área de preservação permanente e reserva legal exceder a:

I - oitenta por cento da propriedade rural localizada na Amazônia Legal;

II - cinquienta por cento da propriedade rural localizada nas demais regiões do País; e

III - vinte e cinco por cento da pequena propriedade definida pelas alíneas "b" e "c" do inciso I do § 20 do art. 10.

Agora, a redação do artigo 15 do NCF:

Art. 15. Será admitido o cômputo das Áreas de Preservação Permanente no cálculo do percentual da Reserva Legal do imóvel, desde que:

I - o benefício previsto neste artigo não implique a conversão de novas áreas para o uso alternativo do solo;

II - a área a ser computada esteja conservada ou em processo de recuperação, conforme comprovação do proprietário ao órgão estadual integrante do Sisnama; e

III - o proprietário ou possuidor tenha requerido inclusão do imóvel no Cadastro Ambiental Rural - CAR, nos termos desta Lei. 
No Novo Código houve um claro afrouxamento deste instituto do cômputo das APP's no cálculo do percentual de Reserva Legal: no artigo 15 e parágrafos do Novo Código, o cômputo não está mais condicionado a um percentual de área de mata nativa mínimo nas APP's, havendo a supressão dos artigos correspondentes a estas exigências. De situação extraordinária no antigo código, o cômputo passou a regra geral no novo. Agora a regra é o cômputo das APP's na RL. Portanto, hoje é menor a exigência do cômputo da APP, que deve, somado à outras áreas que componham a área de RL, corresponder a no mínimo $20 \%$ da propriedade, podendo o excedente da RL acima de um hectare ser negociado como Cota de Reserva Ambiental (ou outras formas de compensação).

\subsection{4: O Cadastro Ambiental Rural (CAR)}

Como vimos na leitura dos dispositivos do artigo 15 do NCF, estes frisam que é necessário o cadastramento do proprietário no Cadastro Ambiental Rural para usufruir do instituto do cômputo, assim como diversos outros procedimentos relativos à regularização ambiental hoje dependem de inscrição no CAR, que se tornou o principal meio de regularização e fiscalização ambiental junto ao Estado, inclusive, havendo hoje a possibilidade de condicionamento do acesso à linhas de crédito para a produção rural somente àquelas propriedades registradas junto ao CAR . O prazo estabelecido para a inscrição era de um ano a contar da implementação do CAR (Lei no 12.651, artigo 29, $\S^{\circ}$ ). O CAR por sua vez só veio a ser plenamente regulamentado pelo Decreto $\mathrm{n}^{\circ} 8.235$ de 5 de maio de 2014, portanto, seria obrigatória para todas as propriedades em posses rurais até 5 de maio de 2015. Às vésperas desta data, entretanto, o prazo foi prorrogado por mais um ano, até 2016 (possibilidade prevista no $\S 3^{\circ}$ do artigo 29)

Baseando-se em um sistema declaratório (online, semelhante ao software do Imposto de Renda), no qual o proprietário averba não só os 
rios, lagos e demais espaços tipificados em lei como de preservação permanente (pela Lei $\mathrm{n}^{\circ} 12.651 / 12$, artigo $4^{\circ}$ ) mas também quais áreas do imóvel estão sendo utilizadas naquele momento da declaração, ou seja, o sistema irá computar estas informações e com base nisto emitir uma estimativa das áreas a serem recompostas, se necessário for. O sistema, então, irá fazer uma análise da propriedade com base em mapas de 2009 e períodos adjacentes, próximos a data fatídica de 22 de julho de 2008 (dia da anistia) e determinar quais áreas estão, de acordo com a Lei $\mathrm{n}^{\circ}$ 12.651/12, consolidadas, possibilitando a aplicação do regime especial de recomposição das ARC.

Vale ressaltar que o CAR se baseia em conceitos de cartografia temática, isto é a precisão é preterida em função de outras informações e dados, utilizando-se de mapas com grandes margens de erro, de até 50 metros (típico da escala 50.000:1), uma vez que os mapas utilizados são recortes de mapas mais extensos, muitos deles coletados ainda nas décadas de 60-70, como é o caso da cartografia hídrica básica ${ }^{24}$.

\subsection{5: Mudanças técnicas nos conceitos de APP's}

Um exemplo muito ilustrativo de uma redução na proteção das APP's foi aquela ocorrida no entendimento acerca do conceito de "Topo de morro". A antiga definição de "Topo de Morro", uma vez que o Código Florestal de 1965 era omisso em sua conceituação, era dada pela Resolução CONAMA 303 de março de 2002, no seu artigo $3^{\circ}$, inciso V:

[Art. $3^{\circ}$ Constitui Área de Preservação Permanente a área situada:] V - no topo de morros e montanhas, em áreas delimitadas a partir da curva de nível correspondente a dois terços da altura mínima da elevação em relação a base.

A nova redação entretanto estabeleceu diversos outros requisitos para a caracterização do "topo de morro", como altura mínima de 100 metros, inclinação média maior que $25^{\circ}$, dando inclusive entendimento diferente

\footnotetext{
${ }^{24}$ LE SANN, Janine Gisele. O Papel da Cartografia Temática nas Pesquisas Ambientais. Revista do Departamento de Geografia da USP no 16 (2005), pág. 61.
} 
daquele da Resolução CONAMA ao conceito de "base de morro", do qual depende o de "topo de morro" 25 . Analisemos:

IX - no topo de morros, montes, montanhas e serras, com altura mínima de 100 (cem) metros e inclinação média maior que $25^{\circ}$, as áreas delimitadas a partir da curva de nível correspondente a $2 / 3$ (dois terços) da altura mínima da elevação sempre em relação à base, sendo esta definida pelo plano horizontal determinado por planície ou espelho d'água adjacente ou, nos relevos ondulados, pela cota do ponto de sela mais próximo da elevação;

Tal mudança, de acordo com estudos recentes, acarretou uma drástica redução da proteção ambiental. Por se tratarem de espaços geomorfologicamente instáveis, reduzir a proteção, isto é, permitir a supressão da vegetação nativa daquele espaço, aumenta em muito as oportunidades de deslizamentos. Com isso, compromete-se a função ecológica do espaço preservado, diminuindo a resiliência local, permitindo assim maiores acidentes e catástrofes, como os que já são recorrentes na região "serrana" (Friburgo, Teresópolis), assim como na Costa Verde (Angra dos Reis, Parati), que já foram palco de devastadores episódios relativos a desabamento por ocupação de morros e encostas.

Outra mudança que vale ser mencionada é a definição da margem dos rios e cursos d'água, isto é do ponto a partir do qual se começa a calcular a largura da APP que antes se contava a partir do nível mais alto. Afirma o antigo código florestal:

Art. $2^{\circ}$ Consideram-se de preservação permanente, pelo só efeito desta Lei, as florestas e demais formas de vegetação natural situadas [...] ao longo dos rios ou de qualquer curso d'água desde o seu nível mais alto em faixa marginal [...]

Hoje sua redação foi alterada para o seguinte:

Art. 4o Considera-se Área de Preservação Permanente [...] as faixas marginais de qualquer curso d'água natural perene e intermitente, excluídos os efêmeros, desde a borda da calha do leito regular [...]

Portanto, além de excluir desta proteção os rios efêmeros, reduziu a proteção dos rios perenes e intermitentes do seu nível mais alto para seu nível regular. Isto pode acarretar grande supressão de mata até então existente (protegida pela legislação anterior) considerando a grande variação que tem alguns rios, em razão de estiagens e outros

\footnotetext{
${ }^{25}$ A Resolução CONAMA n 303 de 2002 estabelece, em seu artigo 2o , inciso IV: "base de morro ou montanha: plano horizontal definido por planície ou superfície de lençol d’água adjacente ou, nos relevos ondulados, pela cota da depressão mais baixa ao seu redor;
} 
fatores climáticos, cuja média da calha do leito é bem menor do que a calha no nível mais alto.

\subsection{6: Levantamento dos dispositivos pertinentes à análise de assentamentos rurais}

Passemos então ao levantamento dos dispositivos normativos pertinentes à análise da adequação de assentamentos rurais de reforma agrária à Nova Legislação Florestal. O artigo 12 do NCF faz referência à Reserva Legal, no caso de $20 \%$ do imóvel. Estabelece no seu parágrafo primeiro que o cálculo da Reserva Legal no caso de fracionamento do imóvel, como é o caso do assentamento Roseli Nunes em que houve o loteamento individual do imóvel original, terá como base a área total do imóvel antes do fracionamento:

Art. 12. Todo imóvel rural deve manter área com cobertura de vegetação nativa, a título de Reserva Legal, sem prejuízo da aplicação das normas sobre as Áreas de Preservação Permanente, observados os seguintes percentuais mínimos em relação à área do imóvel, excetuados os casos previstos no art. 68 desta Lei:

II - localizado nas demais regiões do País: $20 \%$ (vinte por cento).

$\S 1$ o Em caso de fracionamento do imóvel rural, a qualquer título, inclusive para assentamentos pelo Programa de Reforma Agrária, será considerada, para fins do disposto do caput, a área do imóvel antes do fracionamento."

A próxima referência do NCF aos assentamentos de reforma agrária diz respeito à recomposição das Áreas de Preservação Permanente. Esta será realizada com base na área dos lotes individuais, de acordo com o artigo 61-C do NCF:

Art. 61-C. Para os assentamentos do Programa de Reforma Agrária, a recomposição de áreas consolidadas em Áreas de Preservação Permanente ao longo ou no entorno de cursos d'água, lagos e lagoas naturais observará as exigências estabelecidas no art. 61-A, observados os limites de cada área demarcada individualmente, objeto de contrato de concessão de uso, até a titulação por parte do Instituto Nacional de Colonização e Reforma Agrária - Incra.

Levantados os principais dispositivos jurídicos referentes à análise da adequação ambiental, em suas diversas modalidades, de acordo com a extensão do imóvel e as atividades nele desenvolvidas, passemos à investigar a institucionalidade da reforma agrária. 


\section{CAPÍTULO 3: A REFORMA AGRÁRIA NO BRASIL}

\section{1: História}

A debate da reforma agrária não foi sempre pautado por este termo (não encarada como política pública), a problemática agrária antes se dava em um processo atomizado, não havendo uma perspectiva sistemática acerca do assunto, até então geralmente entendida e abordada simplesmente como luta pela terra. A má distribuição da terra no território brasileiro tem suas origens no modelo de dominação português que introduziu, por meio das capitanias hereditárias e, posteriormente, sesmarias, grandes concessões de terra, habitadas (por indígenas) e não habitadas, a administradores coloniais que estabeleceram modelos basicamente monoculturais de culturas tropicais para exportação (açúcar, café, tabaco etc) ${ }^{26}$. Ao fixar estas grandes propriedades, o Estado português deu pouco espaço a um desenvolvimento social fora destas grandes propriedades, cuja produção bastava ao seu sustento, sem necessitar intensamente de trocas, o que retardou o desenvolvimento dos cidades no Brasil, ao focar neste desenvolvimento rural dentro destas estruturas administrativas de concessão.

$\mathrm{O}$ ano de 1850 marca definitivamente o fim do período da obtenção de terra por meio da posse com o advento da Lei de Terras, que é promulgada neste ano, introduzindo o sistema cartorial no Brasil. Estabelecia que toda terra deveria ser adquirida por meio da compra, existindo um título, registrado em cartório, correspondente, desvinculando a propriedade de seu uso efetivo (jus possidetis). Ao fazê-lo além de exigir a capacidade civil do proprietário, assim excluindo escravos, mulheres, além de outros, os analfabetos também estariam prejudicados (em época na qual a condição prevalecia sobre a maior parte da população), além de forçar estas e outras camadas sociais menos privilegiadas como os imigrantes que

\footnotetext{
${ }^{26}$ MEDEIROS, Leonilde Servolo. Reforma agrária no Brasil: História e atualidade da luta pela terra, São Paulo: Editora Fundação Perseu Abramo, 2003. Pág. 9.
} 
chegavam, a venderem sua mão-de-obra para os grandes cafezais. Além disto, é notório o processo de expropriação, principalmente de povos tradicionais (indígenas, ribeirinhos, caiçaras, populações mais pobres) que ocorreu deste ato legal, com a declaração de propriedade sobre grandes áreas (sem possuir, necessariamente o direito sobre elas) por parte de indivíduos dos estratos sociais mais próximos aos poderes locais, típicos do coronelismo de que nos fala Vitor Nunes Leal ${ }^{27}$. Em 1888, com a Lei Áurea, houve à época, indícios de um debate sobre políticas fundiárias para inserção social dos emancipados, mas foi silenciado pelos setores mais conservadores (ligados à terra), agravando a condição sócio-espacial da população negra, que se viu substituída progressivamente pela mão-de-obra imigrante que aportava abundante com forte incentivo estatal. ${ }^{28}$

Durante as décadas seguintes, o debate acerca do tema se encontrou atomizado e casuístico. Há, em meados dos anos 20, tentativas de setores mais progressistas, em parte do movimento tenentista, de incluir a pauta da reforma agrária na Constituição de 1934, sem sucesso. Há com o Estado Novo a inauguração da Consolidação das Leis do trabalho (CLT) ${ }^{29}$, entretanto, devido às peculiaridades da estruturação do trabalho no espaço agrário, às práticas como parcelamentos de terras, a caracterização na categoria "assalariado/a" era muito dificultada, obstando o acesso às garantias jurídicas da classe.

Em 1950 começa a haver a popularização do léxico "reforma agrária", que antes encontrava seu uso restrito a meios intelectuais e políticos, e uma reunião de diferentes movimentos Brasil a fora, que antes se encontravam atomizados e em âmbito local, sob essa bandeira, muito por causa dos esforços realizados pelo Partido Comunista Brasileiro (PCB) na politização das populações rurais. Àquela época, o PCB pautava a reforma agrária com base nas diretrizes da Internacional Comunista (sem

\footnotetext{
${ }^{27}$ LEAL, Victor Nunes. Coronelismo, Enxada e Voto: o município e o regime representativo no Brasil. São Paulo: Editora Companhia das Letras, 2012. Pág. 44.

${ }^{28}$ MEDEIROS, Leonilde Servolo. Reforma agrária no Brasil: História e atualidade da luta pela terra, São Paulo: Editora Fundação Perseu Abramo, 2003. pág. 11.

${ }^{29}$ Ibid. pág. 12
} 
necessariamente tomar como base a realidade fática dos movimentos existentes). Focalizava seus esforços na dissolução de instituições que eram vistas então como feudais (e até hoje são sinais de atraso) tais como o latifúndio, mas também os barracões, que geravam/geram as escravidões por dívida, assim como a luta por direitos trabalhistas e sociais no campo. Durante a década de 50, houve a ascensão de outros movimentos que viriam a ter papel fundamental na luta pela terra. A primeira que podemos citar foram as Ligas Camponesas (que, fundadas com ajuda do PCB em meados de 1945, mas proibidas por Getúlio, retornando em 1954), que organizavam cooperativamente assistência técnica, jurídica, educacional, creditícia e funerária, de maneira a empoderar os camponeses frente ao latifúndio ${ }^{30}$.

Durante a década de 60, assistimos a uma efervescência da pauta. As Ligas Camponesas estavam se consolidando no Nordeste, constando algumas vitórias contra o latifúndio. Em 1962 há criação de norma que prevê a possibilidade da criação de Sindicatos Rurais. Já em 1963 vem a aprovação do Estatuto do Trabalhador Rural (Lei 4.214 de 2 março de 1963) garantindo direitos trabalhistas aos trabalhadores do campo ${ }^{31}$. Em janeiro de 1964, é fundada a Confederação Nacional dos Trabalhadores na Agricultura (CONTAG), que viria a ser a principal entidade da luta pela terra até a década de 80. O Governo de João Goulart anuncia em 13 de março de 1964, durante o episódio que viria a ser chamado de "Comício da Central", a elaboração de profundas políticas agrárias e sociais que incluem desapropriações por interesse social tanto de grandes extensões de terra valorizadas por investimentos públicos ao longo das ferrovias e açudes (por meio do Decreto 53.700 sancionado naquele mesmo dia) quanto de refinarias privadas de petróleo. Isto levou os setores mais ligados ao latifúndio, historicamente privilegiados, concentradores de poder, a uma reação fortíssima, que veio a resultar nas Marchas com Deus pela Família de 19 de março (e conseguintes), propondo a demonstrar o poder popular

\footnotetext{
${ }^{30}$ Ibid. Pág. 17.

${ }^{31}$ Ibid. Pág. 22
} 
que resistia àquelas reformas, que temendo a instauração de uma ditadura comunista, inicia a circulação de um "Manifesto ao Povo Brasileiro" seguindo-se disso o fatal Golpe Militar de $1^{\circ}$ de abril de 1964. O referido Decreto 53.700 foi revogado em 13 de abril.

Uma das primeiras medidas da ditadura militar foi se voltar para a questão agrária, que assistia a grande aceleração de dinâmicas sociais divergentes, ainda impulsionadas pelo Governo Jango. Há, com o Estatuto da Terra (Lei no 4.504 de 30 de novembro de 1964), uma apropriação pelo Estado, por meio da tipificação legal de termos políticos, como por exemplo, a categoria de latifúndio. E apesar de criar institutos potencialmente transformadores da estrutura agrária, a Lei não encontrou exeqüibilidade política no cenário político da época, além de se insistir, na prática da época, no modelo de colonização para expansão da fronteira agrícola, o que planejava assentamentos muito distantes, com pouca capacidade de escoamento, além de baixa resiliência, o que contribui para o fracasso de muitos destes.

Houve durante a ditadura, diversos programas de incentivo não só à expansão da fronteira agrícola sob uma perspectiva de "Modernização Conservadora" ${ }^{, 32}$, com farto crédito à empresas agrícolas para mecanização da produção, a utilização de insumos químicos, além de disponibilização de grandes extensões de terra, muitas vezes griladas $^{33}$, expropriadas ilegalmente, o que atrau várias empresas de outros segmentos comerciais e industriais para a agricultura. Com isto ganhava força o argumento da grande propriedade produtiva, resultante das dinâmicas da, então recente, dita "Revolução verde" (que reforçava-se com estas políticas de

\footnotetext{
${ }^{32}$ CALDART, Roseli Salete et ali (org). Dicionário da educação no campo. SãoPaulo: Editora Expressão popular, 2012. Pág. 482

${ }^{33}$ Como é exposto em "A questão fundiária na Amazônia", LOUREIRO,Violeta Refkalevsky e PINTO, Jax Aragão, que pode ser obtido online no endereço: http://www.scielo.br/scielo.php?script=sci arttext\&pid=S0103-40142005000200005, acessado em 09/06/2015

34 “a Revolução Verde foi concebida como um pacote tecnológico - insumos químicos, sementes de laboratório, irrigação, mecanização, grandes extensões de terra - conjugado ao difusionismo tecnológico, bem como a uma base ideológica de valorização do progresso.” In CALDART,
} 
concentração de terra), e por outra mão, contestava-se a necessidade da alteração das estruturas fundiárias por meio de uma reforma agrária e da eficiência do modelo familiar e campesino.

É no começo da década de 1980 que há o surgimento de novos atores no cenário da luta pela terra e reforma agrária. Começam a surgir as vítimas do projeto desenvolvimentista: as grandes hidrelétricas, que viriam a fornecer energia para uma indústria crescente e para as cidades em um contexto de um dos mais rápidos êxodos rurais da história do mundo, que acarretam diversas e extensas remoções, havendo o aparecimento de organizações dos Removidos por Barragens; a resistência das culturas extrativistas frente a expansão da fronteira agrícola e o desmatamento, e a organização de movimentos de seringueiros; a efervescência de diversos trabalhadores sem terra que reivindicavam reformas estruturais e políticas de acesso à terra, que começavam a ocupar algumas terras, especialmente na região Sul. Apesar de não necessariamente estarem ligados ao ambientalismo como ideologia, estes grupos estavam levantando a questão ambiental (como é flagrante no caso dos seringueiros) e sua fragilidade, mas também sua resistência frente ao "progresso" do ocidente capitalizado, e começam a se reunir em torno de uma questão comum: a luta pela terra. A década referida assistiu a duas dinâmicas muito importantes para institucionalização do tema da reforma agrária. Estes grupos que por diferentes motivos se viam privados da terra se uniram em organizações, que tiveram papel muito importante na redemocratização do país. Os seringueiros, se reuniram em um movimento, sob liderança de Chico Mendes, após a morte de Wilson Pinheiro, desde final da década de 70 .

Houve a criação do Movimento dos Atingidos por Barragens (MAB) entre 1985/1986, e entre 1984 e 1985 é fundado o MST. Outro ator muito 
importante foi a Pastoral da Terra ${ }^{35}$, fundada em 1975, que naquela época encampa a luta pela terra, sendo muito importante para dar apoio e visibilidade à questão da reforma agrária, inclusive inserindo-a no discurso cristão, o que permitiu sua permeabilidade em diferentes estratos sociais. Em 1985 há, devido à forte pressão dos movimentos sociais, que efervesciam voltando a se manifestar aberta e organizadamente no período de abertura democrática, a apresentação, pelo então Presidente José Sarney, do Programa Nacional de Reforma Agrária (PNRA I). Tendo contado com apoio e colaboração da CONTAG, que à época já encontrava resistência por parte de outros movimentos demandantes de terra e muitas críticas ao seu molde centralizador, ao seu suposto monopólio da representação laboral da classe trabalhadora rural, o PNRA já não encontrou a mesma receptividade de movimentos sociais como o MST e a CUT, que mantinham uma postura de desconfiança em relação às promessas do Governo. $\mathrm{O}$ dia seguinte ao anúncio do PNRA I foi marcado por uma série de ocupações em Santa Catarina, organizadas pelo MST, o que, desde então, o colocou em uma posição de destaque nacional, como maior interlocutor da reforma agrária.

O PNRA I visava assentar 7 milhões de pessoas em 15 anos $^{36}$, entretanto prestigiava as entidades sindicais rurais, em especial a Contag, em detrimento dos movimentos sociais difusos ascendentes. Entretanto foi por meio dele que extinguiu-se o INCRA, transferidas suas competências para o MIRAD ${ }^{37}$ em 1987 (mediante o Decreto-Lei n.o 2.363, de 21 de outubro de 1987) sendo recriado pelo Congresso Nacional em 1989 (Decreto Legislativo $\mathrm{n}^{\circ}$ 2). Em época próxima ao anúncio do PNRA I, a classe proprietária funda a União Democrática Ruralista (UDR) objetivando não só combater as propostas do Plano, que era considerado uma ameaça

\footnotetext{
${ }^{35}$ A Pastoral da Terra foi ala da Igreja Católica que assumiu as pautas e lutas campesinas. Foi muito influente desde os anos 50 e sempre forte formadora de opinião, além de aliada valiosa de outros movimentos da luta pela Terra, tendo apresentado oposição aos projetos nacionais quando entendia estes como pactos conservadores (como aconteceu com o Plano Nacional da Reforma Agrária e a Cédula da Terra)

${ }^{36}$ MEDEIROS, Leonilde Servolo. Reforma agrária no Brasil: História e atualidade da luta pela terra, São Paulo: Editora Fundação Perseu Abramo, 2003. Pág. 35.

${ }^{37}$ Ministério Extraordinário para o Desenvolvimento e a Reforma Agrária
} 
aos interesses, mas defender a grande propriedade dentro de um contexto de modernização conservadora, além das posições de poder da elite agrária, que se via contestada cada vez mais por movimentos sociais no campo ${ }^{38}$. A UDR foi muito importante na inclusão de dispositivos constitucionais como o inciso II do artigo 185, que condiciona a desapropriação ao conceito de improdutividade, impedindo-a nos casos de imóvel "produtivo". Foi durante o processo constituinte que a UDR se consagra como ator político com ampla adesão social: tendo mobilizado uma "Caminhada Cívica" que ocupou a Esplanada até o Congresso Nacional, se consolida como representação da classe proprietária, assumindo uma postura ofensiva: chegando a apoiar práticas como acampamentos nas fazendas de maneira a combater com isso a ocupação por movimentos sociais. ${ }^{39}$

O período da Constituinte foi muito disputado por todos os setores da sociedade brasileira, havendo efervescência de movimentos sociais, e forte participação de organizações como a CONTAG, a Pastoral da Terra, o MST entre outros, estando as sessões referentes à reforma agrária entre as mais tumultuadas do processo constituinte. Desde 1988 a reforma agrária tem previsão constitucional, distribuída em alguns dispositivos da Magna Carta. Primeiramente, há no artigo $5^{\circ}$ (além da função social da propriedade do inciso XXIII) inciso XXIV, a previsão da desapropriação por três motivos básicos: necessidade pública, utilidade pública ou interesse social. É, inclusive, constitucionalmente prevista a competência privativa da União para legislar sobre direito agrário (artigo 22, inciso I) e desapropriação (artigo 22, inciso II).

Em seguida, o tema será tratado mais pormenorizadamente no Capítulo III do Título VII da Constituição, sob o título de "Da Política Agrária e Fundiária e Da Reforma Agrária”, a partir do seu artigo 184 e seguintes. Nos dispositivos que constituem esse artigo são previstos diversos princípios que permearão o resto do ordenamento referente à

\footnotetext{
${ }^{38}$ PILATTI, Adriano. Marchas de uma Contramarcha: Transição, UDR e Constituinte. Dissertação (Mestrado em Direito) - Pontifícia Universidade Católica do Rio de Janeiro, 1988. Pág. 49.

${ }^{39}$ Ibid. Pág. 75
} 
matéria, tais como: a indenização do imóvel desapropriado ser efetuada mediante Títulos da Dívida Agrária (artigo 184, caput, C.F.), a previsão obrigatória da indenização em dinheiro pelas benfeitorias dos imóveis desapropriados ( $\$ 1^{\circ}$, artigo 184 , C.F.), a autorização para proposição de ação de desapropriação a partir da emissão da declaração de improdutividade (\$2, artigo 184, C.F.), a insuscetibilidade à desapropriação da pequena e média propriedade, assim como da propriedade produtiva (artigo 185, incisos I e II, C.F.), requisitos gerias da função social da propriedade (artigo 186, que já delineia melhor a previsão abstrata do artigo $5^{\circ}$, inciso XXIII, C.F.)

Durante o Governo Itamar Franco ocorrem mudanças importantes na institucionalidade da reforma agrária: a edição da Lei 8.629/93, conhecida como Lei Agrária. Além dela a Lei Complementar 76, promulgada logo após a 8.629, que determinava os ritos do processo de desapropriação, de forma teoricamente mais célere, pela adoção do procedimento sumário. Estas leis vieram a regulamentar a classificação das propriedades, possibilitando novamente o instituto jurídico da desapropriação para fins de reforma agrária, que se encontrava suspenso por falta de previsão infraconstitucional desde a promulgação da Constituição de 88 .

No Governo Fernando Henrique Cardoso ocorrem mudanças marcantes na institucionalidade da reforma agrária. Há a tentativa (bemsucedida na medida em que alguns de seus dispositivos ainda permeiam o ordenamento jurídico) de inserção de diversos mecanismos de obtenção de terra via mercado. Contando com o financiamento do Banco Mundial, inaugura-se no Estado do Ceará espalhando-se para outros Estados o Programa "Cédula da Terra" ${ }^{40}$, que instaurava uma nova lógica à reforma agrária: em detrimento das ocupações, agora iria se privilegiar a negociação para compra do proprietário. Considerado um sucesso pelo Banco Mundial, o programa começa a se espalhar pelo país, até ganhar uma nova

\footnotetext{
${ }^{40}$ MEDEIROS, Leonilde Servolo. Reforma agrária no Brasil: História e atualidade da luta pela terra, São Paulo: Editora Fundação Perseu Abramo, 2003. Pág. 58.
} 
plataforma: O Banco da Terra, que visava pulverizar o programa "Cédula da Terra" por todo o Brasil ${ }^{41}$. O Governo FHC contribui com isso para o endividamento de mais agricultores por todo o território, que perderam suas terras, acelerando ainda mais o Êxodo Rural neste período.

$\mathrm{O}$ período $\mathrm{FHC}$ também se caracteriza pela forte repressão à ocupações para reforma agrária. Em 15 de julho de $1995^{42}$ ocorre o Massacre de Corumbiara em Roraima e em 17 de abril de $1996^{43}$, o Massacre de Eldorado dos Carajás. Mesmo com repressão estatal à ocupação de terras foi neste período em que se criou mais assentamentos de Reforma Agrária, não por conta de um planejamento pelo Estado, mas por força das ocupações lideradas, na grande maioria das vezes, pelo MST. Estima-se que foram assentadas 579.733 famílias, excluindo aquelas 55.302 assentadas por meio do Banco da Terra. ${ }^{44}$

Há em 2001 a instituição da Medida Provisória no 2183-56 (após uma suposta invasão à uma fazenda de propriedade do então presidente FHC, que em retaliação institui o decreto referido) que veio trazer alguns dispositivos e alterar outros (como é o caso dos parágrafos $6^{\circ}$ e $7^{\circ}$ do artigo $2^{\circ}$ da Lei 8.629/93) visando, de fato, dificultar a vistoria dos imóveis, impedindo-a no caso do imóvel já estar ocupado (que, como veremos acarretará mudanças nas dinâmicas das ocupações).

Em 2003, já no primeiro ano de Governo Lula, é estabelecido o II Plano Nacional de Reforma Agrária, estendendo os benefícios destas políticas públicas às populações ribeirinhas, não-indígenas ocupantes de reserva indígena, comunidades rurais tradicionais, atingidos por barragens entre outros grupos, que mesmo não estando engajados diretamente na produção agrícola, estão ligados a ela. O PNRA II terminou em 2007, sem,

\footnotetext{
${ }^{41}$ Ibid.

${ }^{42}$ http://www.mst.org.br/nossa-historia/94-95, última vez acessado em 12/05/2015

${ }^{43} \mathrm{http}: / /$ www.mst.org.br/nossa-historia/96, última vez acessado em 12/05/2015

${ }^{44}$ MEDEIROS, Leonilde Servolo. Reforma agrária no Brasil: História e atualidade da luta pela terra. São Paulo. Editora Fundação Perseu Abramo, 2003, Pág. 74.
} 
entretanto, alcançar as metas esperadas ${ }^{45}$. Não há previsão de um terceiro plano ainda.

\section{2: Do processo de desapropriação por interesse social para} fins de reforma agrária

Para a elaboração deste ponto específico foram realizadas algumas visitas à sede do Instituto Nacional de Colonização e Reforma Agrária (INCRA) do Rio de Janeiro, nas quais foram realizadas entrevistas com técnicos do Instituto, alguns deles, inclusive, que participaram do processo de desapropriação do Projeto de Assentamento (PA) Roseli Nunes.

“O processo de desapropriação tem como base dois objetos: terras (propriedades imóveis) e pessoas" ${ }^{\text {46 }}$. Como vimos, pode se dar mediante interesse social, utilidade pública ou necessidade pública, sendo a por interesse social a única modalidade de desapropriação constitucionalmente permitida a realizar o pagamento das indenizações via Título da Dívida Agrária, e esta por sua vez só pode ser realizada pela União.

O requisito básico para a desapropriação por interesse social é o não cumprimento da função social de uma propriedade. A Constituição, no seu artigo 186, enumera os requisitos da configuração desta função social:

Art. 186. A função social é cumprida quando a propriedade rural atende, simultaneamente, segundo critérios e graus de exigência estabelecidos em lei, aos seguintes requisitos:

I - aproveitamento racional e adequado;

II - utilização adequada dos recursos naturais disponíveis e preservação do meio ambiente;

III - observância das disposições que regulam as relações de trabalho;

IV - exploração que favoreça o bem-estar dos proprietários e dos trabalhadores.

Importante atentar à discussão sobre se os requisitos devem ser preenchidos simultaneamente, e que o não cumprimento de um deles seria o suficiente para, com base no descumprimento da função social, iniciar um

\footnotetext{
${ }^{45}$ Críticas ao PNRA II: http://www.brasildefato.com.br/node/3444, acessado em 05/06/2015

${ }^{46}$ Declaração colhida de técnico do INCRA durante entrevista em 27/05/2015
} 
processo de desapropriação. Esta discussão é bem recente e foi resgatada também pelas discussões da PEC do trabalho escravo (que permitiria a expropriação das propriedades que se utilizassem destas práticas). Grande empecilho a este entendimento é o disposto no inciso II do artigo 185 da Constituição que estabelece que não será desapropriada a propriedade produtiva. Isto tem levado a uma interpretação restritiva do artigo 186, condicionando a desapropriação a somente um dos quatro requisitos da função social, a produtividade (aproveitamento racional e adequado). Mas suscita-se a dúvida, é "produtivo" (socialmente) um imóvel que explora seus recursos de maneira insustentável?

O processo de desapropriação por interesse social começa com a notificação do proprietário do imóvel quanto à elaboração, pelo Instituto de Colonização e Reforma Agrária (INCRA) do Laudo Agronômico de Fiscalização (LAF), realizado por equipe multidisciplinar de acordo com o $\S 3^{\circ}$ do artigo 12 da Lei 8.629/93 que é uma vistoria no local do imóvel que se visa desapropriar, que , devido ao modelo casuístico, é majoritariamente decorrente de uma ocupação ${ }^{47}$, apesar dos entraves legais à esta prática ${ }^{48}$. Sendo um levantamento da situação ambiental, geomorfológica, o LAF estipula uma estimativa, calculada a partir de critérios de produtividade do local, baseando-se em índices (Grau de Eficiência na Exploração -GEE, e o Grau de Utilização da Terra -GUT), e emite uma avaliação quanto a viabilidade de um projeto de assentamento ser realizado ali além de quantas famílias poderão ser ali alocadas, em quantos lotes se parcelará a propriedade, aproximadamente (uma vez que esta decisão será tomada mais

\footnotetext{
${ }^{47}$ De acordo com o $\$ 6^{\circ}$ do artigo $2^{\circ}$ da Lei $n^{\circ} 8.629$, os técnicos do INCRA não poderiam fazer a avaliação quando o imóvel estivesse sendo "invadido", de acordo com a mudança introduzida na Lei 8.629 pela Medida Provisória 2.183-56 (esta Medida foi alterada 56 vezes, em um contexto temporal próximo ao evento da invasão da Fazenda do então presidente FHC), no seu artigo $2^{\circ}$, $\S 6^{\circ}$.

48 "Durante os últimos anos do Governo do ex-Presidente da República Fernando Henrique Cardoso, devido à edição da Medida Provisória n. 2.027/2000, que impedia a vistoria por dois anos das propriedades que fossem "invadidas", o MST mudou sua tática política, passando a acampar em beiras de estradas ou ocupar propriedades que não estivessem incluídas no programa de Reforma Agrária, mas as que fossem limítrofes daquelas." (QUINTANS, Mariana. A Magistratura Fluminense: seu olhar sobre as ocupações do MST. 2005. Dissertação (Mestrado em Direito) - Pontifícia Universidade Católica do Rio de Janeiro p.78).
} 
definitivamente pelos próprios assentados, durante a realização do Plano de Desenvolvimento do Assentamento). Este Laudo irá tramitar pelo INCRA até chegar à Presidência da República que baixará um Decreto que declara de interesse social para fins de Reforma Agrária determinado imóvel permitindo a instauração do processo de desapropriação. Daí, antes da propositura da ação é necessária a elaboração de um Laudo de Vistoria e Avaliação $(\mathrm{LVA})^{49}$, que conterá as informações relevantes para o levantamento de um valor a ser pago a título de indenização, discriminando as benfeitorias ${ }^{50}$ que serão pagas em dinheiro e o passivo ambiental, que será descontado da indenização. Com base nestes valores desapropriatórios constantes do LVA poderá ser proposta a Ação de desapropriação. O rito previsto para este processo é o sumário (de acordo com artigo $1^{\circ}$ da Lei Complementar 76 de 1993), devendo, de acordo com o artigo $6^{\circ}$ da LC 76/93, dentro de 48 horas do despacho da petição inicial, haver pronunciamento do juiz acerca da imissão na posse do autor, a notificação do proprietário e averbação da presente ação no cartório onde está registrado o imóvel. A ação será proposta pelo INCRA e julgada por juiz federal, mesmo que durante as férias forenses ( $\operatorname{LC} 76$, artigo $\left.1^{\circ}, \S 1^{\circ}\right)$. Há um prazo decadencial de 2 anos para a propositura da Ação de desapropriação a contar da publicação do Decreto que declara de interesse social o imóvel que se visa desapropriar.

Cabe ressaltar que vale recurso contra os atos administrativos da desapropriação, tais como a aplicação equivocada dos índices do LAF, como o Grau de Utilização da Terra (GUT) ou o Grau de Eficiência na Exploração (GEE), ou dos valores financeiros arbitrados no LVA etc, mas não contra a decisão administrativa que considerou de interesse social o

\footnotetext{
${ }^{49}$ Cabe ressaltar aqui que ambos o LAF e o LVA são realizados com base em dados cartográficos das décadas de 60-70, de escala muito pouco precisa e margem de erro bem alta, sem um georreferenciamento do imóvel. Como veremos ao longo da presente investigação, isto ocasionará algumas contradições. Além disso, não há critérios objetivos padronizados para elaboração da estimativa da indenização pelos técnicos do INCRA, o que impinge demasiada subjetividade ao procedimento, além de diminuir a segurança jurídica, aumentando as chances de impugnação deste.

${ }^{50}$ Que podem ser reprodutivas, isto é, cultivos realizados no imóvel, ou não-reprodutivas, edifícios, construções.
} 
imóvel: este ato discricionário, baseado em critérios de conveniência e oportunidade do poder público, não podendo ser mérito da impugnação pelo proprietário. A posição da Magistratura é, em geral, conservadora quando o mérito da ação se trata de ocupação para reforma agrária ${ }^{51}$, em todos os níveis do Judiciário. É notável esta característica quando atentamos à produção de súmulas do $\mathrm{STF}$ acerca do tema, em especial nas súmulas $\mathrm{n}^{\circ}$ $345^{52}$ e $618^{53}$.

Após este momento, havendo a desapropriação do imóvel e sua incorporação à União, há o contato e cadastramento das famílias que estão ocupando o imóvel junto ao Cadastro Único (para programas sociais CAD).

Estas pessoas serão então submetidas à uma análise de adequação às exigências legais à inscrição no Programa de Reforma Agrária (do Governo Federal), havendo, então, a eliminação daqueles não habilitados. Podemos encontrar no artigo 20 da Lei $n^{\circ} 8629 / 93$, alguns desses requisitos legais os quais devem ser preenchidos pelos assentados (além do $\S 7^{\circ}$ do artigo $2^{\circ}$ da Lei 8.629/93):

Art. 20. Não poderá ser beneficiário da distribuição de terras, a que se refere esta lei, o proprietário rural, salvo nos casos dos incisos I, IV e V do artigo anterior, nem o que exercer função pública, autárquica ou em órgão paraestatal, ou o que se ache investido de atribuição parafiscal, ou quem já tenha sido contemplado anteriormente com parcelas em programa de reforma agrária.

Em seguida, com base na estimativa (capacidade $=$ quantidade + qualidade do imóvel $\mathrm{X}$ quantidade de pessoas) prevista no LAF será elaborado balanço da capacidade demográfica do imóvel, de quantas pessoas poderão ser alocadas ali. No caso de haverem mais pessoas ocupando o imóvel do que a estimada capacidade do PA, o destino das pessoas não alocadas será, ou engrossar outra ocupação, ou combinando

\footnotetext{
${ }^{51}$ Suscita-se na pesquisa "A Magistratura Fluminense: seu olhar sobre as ocupações do MST" uma identificação da classe proprietária, até pelo costume da elite brasileira de investir na aquisição de terras.

${ }^{52} \mathrm{Na}$ chamada desapropriação indireta, os juros compensatórios são devidos a partir da perícia, desde que tenha atribuído valor atual ao imóvel.

${ }^{53} \mathrm{Na}$ desapropriação, direta ou indireta, a taxa dos juros compensatórios é de $12 \%$ (doze por cento) ao ano.
} 
com um dos assentados do local, ficar na área e esperar até que vague um lote. Daí, com base na relação destas pessoas cadastradas junto ao CAD, legalmente habilitadas, e inseridas na estimativa de habitantes do assentamento, observada a ordem de preferência constante dos dispositivos do artigo 19 da Lei n ${ }^{\circ}$ 8.629/93, será emitida uma Relação de Beneficiários. Esta deverá prever quais famílias terão direito ao Contrato de Concessão de Uso (CCU - sendo ainda possíveis as modalidades título de domínio e concessão de direito real de uso, de acordo com o artigo 18 da Lei 8.629), lembrando que área de cada lote individual não ultrapassará dois módulos fiscais (artigo 18-A). Há, inclusive, previsão do da conversão do CCU em título definitivo de propriedade. Para tanto devem ser cumpridas três obrigações por parte dos assentandos:

1- Registrar o título referente ao imóvel em cartório competente (Registro de Imóveis): no caso, antes do título de propriedade propriamente dito, há o contrato de concessão de uso com cláusula resolutiva em propriedade, que também deve ser declarado no Registro de Imóveis, que se aperfeiçoa uma vez cumpridos os outros dois requisitos, devendo após cumpridos, serem levados para registro. As custas e emolumentos não serão cobradas por esse registro de título (artigo 26-A, Lei $n^{\circ} 8.629 / 93$ ), assim como não incidirão os impostos sobre as transferências de propriedade (artigo 26, Lei $\mathrm{n}^{\circ}$ 8.629/93), revelando o caráter gratuito reservado aos assentados nestes procedimentos, por força de sua hipossuficiência;

2- Quitar o pagamento: Com base nos valores pagos ao proprietário, e após divisão deste valor pelas áreas parceladas em lotes, observadas as assimetrias e peculiaridades de cada lote, o que faz com que cada lote tenha um valor pecuniário diferente, cada família terá que pagar pelo seu lote. $\mathrm{O}$ pagamento deve ser efetuado em, no máximo, vinte anos, podendo ser parcelado em 17 vezes, havendo ainda a possibilidade de carência dos primeiros três anos, até como forma de permitir ao assentado pagar este débito com os recursos financeiros obtidos com o trabalho desempenhado no seu lote; 
3- O assentado deve ter mantido no imóvel suas características rurais, além de habitar o imóvel e tê-lo explorado diretamente (sem cedê-lo a terceiros), durante 10 (dez) anos (artigo 21 da Lei 8.629/93).

Após preenchidos estes requisitos há a liberação das condições resolutivas e conversão do CCU em título de propriedade. Mesmo que as duas primeiras obrigações sejam quitadas antes de decorridos os 10 anos, só será aperfeiçoada a propriedade e sua alienabilidade após decorrido este prazo, de maneira a cumprir a terceira obrigação supra-citada. Além disso, há a previsão de rescisão contratual no caso de o assentado descumprir com uma de suas obrigações, acarretando no retorno do imóvel ao órgão alienante (artigo 22 e parágrafos, Lei no 8.629/93), incluindo nesta hipótese de rescisão a desobediência às diretrizes do Ordenamento Territorial no caso de Reforma Agrária, portanto no espaço rural, de competência da União, o imóvel desapropriado integrará o patrimônio da União.

A indenização ao antigo proprietário poderá se dar de duas formas: a primeira, da terra nua (só o terreno), será mediante expedição de Títulos da Dívida Pública (TDA), de acordo com o artigo $5^{\circ}$ caput da Lei $\mathrm{n}^{\circ}$ 8.629/9354, com resgate a partir do segundo ano da emissão até desde o décimo quinto ao vigésimo ano, variando de acordo com o tamanho da propriedade (definida em módulos fiscais - incisos do parágrafo $3^{\circ}$, artigo $5^{\circ}$, Lei no 8629). É prevista, entretanto, uma indenização prévia em dinheiro para as benfeitorias presentes no imóvel, a ser deduzida do montante total da indenização (artigo 12, §1 ${ }^{\circ}$, Lei $n^{\circ}$ 8629). Estas informações referentes ao débito (pelas terras nuas e benfeitorias) constarão do Título de cada lote onde estas se encontravam (principalmente no caso das benfeitorias, culturas produtivas consolidadas, como seria o caso dos eucaliptos, que ocorreu no Roseli Nunes, e será tratado mais pormenorizadamente a frente) - Vale frisar neste ponto, que de acordo com o caput do artigo 12, a indenização pela desapropriação será feita com base nos valores de

\footnotetext{
54 “Art. $5^{\circ} \mathrm{A}$ desapropriação por interesse social, aplicável ao imóvel rural que não cumpra sua função social, importa prévia e justa indenização em títulos da dívida agrária."
} 
mercado. Esse dispositivo legal expressa a mudança que se deu no período FHC, em que a desapropriação perdeu boa parte de seu caráter sancionatório sobre o imóvel improdutivo. Tornando a improdutividade, potencialmente, um bom negócio.

Vale lembrar que a Constituição Federal de 1988 não permite a desapropriação de pequenos e médios imóveis para reforma agrária, mesmo que improdutiva, com exceção desta regra no caso do proprietário possuir outro imóvel rural(artigo 185, inciso I, C.F. e parágrafo único do artigo $4^{\circ}$ da Lei $n^{\circ}$ 8629/93) além de vetar também a desapropriação de propriedade produtiva (artigo 185 inciso II). Para a conceituação de pequena e média propriedade nos servimos daquela legalmente constituída na Lei n ${ }^{\circ} 8.629$ de 1993, em seu artigo $4^{\circ}$, incisos II e III, que estabelece a pequena propriedade com área compreendida entre um e quatro módulos fiscais; e média a propriedade com área superior a quatro até quinze módulos fiscais.

A Lei $\mathrm{n}^{\circ} 8.629$ de 93 também veio a refinar ainda mais o conceito de produtividade, tão caro ao processo de desapropriação, subordinando-o ao conceito de exploração racional cuja Lei estabelece como índices de utilização e eficiência na exploração da terra que serão definidos no artigo $6^{\mathrm{o}}:$

Art. $6^{\circ}$ Considera-se propriedade produtiva aquela que, explorada econômica e racionalmente, atinge, simultaneamente, graus de utilização da terra e de eficiência na exploração, segundo índices fixados pelo órgão federal competente. $\S 1^{\circ} \mathrm{O}$ grau de utilização da terra, para efeito do caput deste artigo, deverá ser igual ou superior a $80 \%$ (oitenta por cento), calculado pela relação percentual entre a área efetivamente utilizada e a área aproveitável total do imóvel.

$\S 2^{\circ} \mathrm{O}$ grau de eficiência na exploração da terra deverá ser igual ou superior a $100 \%$ (cem por cento), e será obtido de acordo com a seguinte sistemática:

I - para os produtos vegetais, divide-se a quantidade colhida de cada produto pelos respectivos índices de rendimento estabelecidos pelo órgão competente do Poder Executivo, para cada Microrregião Homogênea;

II - para a exploração pecuária, divide-se o número total de Unidades Animais (UA) do rebanho, pelo índice de lotação estabelecido pelo órgão competente do Poder Executivo, para cada Microrregião Homogênea;

III - a soma dos resultados obtidos na forma dos incisos I e II deste artigo, dividida pela área efetivamente utilizada e multiplicada por 100 (cem), determina o grau de eficiência na exploração.

$\S 3^{\circ}$ Considera-se efetivamente utilizadas:

I - as áreas plantadas com produtos vegetais;

II - as áreas de pastagens nativas e plantadas, observado o índice de lotação por zona de pecuária, fixado pelo Poder Executivo; 
III - as áreas de exploração extrativa vegetal ou florestal, observados os índices de rendimento estabelecidos pelo órgão competente do Poder Executivo, para cada Microrregião Homogênea, e a legislação ambiental;

IV - as áreas de exploração de florestas nativas, de acordo com plano de exploração e nas condições estabelecidas pelo órgão federal competente;

$\mathrm{V}$ - as áreas sob processos técnicos de formação ou recuperação de pastagens ou de culturas permanentes, tecnicamente conduzidas e devidamente comprovadas, mediante documentação e Anotação de Responsabilidade Técnica."

Entretanto, acertou o legislador a subordinar a exploração racional à função social da propriedade que, de acordo com os dispositivos do artigo $9^{\circ}$ deste diploma, significa não só a exploração racional, como o uso adequado dos recursos naturais (no caso, uma função sócio-ambiental da propriedade), além de respeito às relações de trabalho e bem-estar dos trabalhadores, havendo hoje a possibilidade de desapropriação por interesse social quando não preenchidos estes requisitos ${ }^{55}$.

\section{3: O MST e a Reforma Agrária: Perspectiva Nacional}

“Ocupação é a única solução!” foi o lema do I Congresso do MST, realizado em 1985, que definiu as diretrizes do Movimento: a luta pela terra, a reforma agrária e o socialismo.

De lá pra cá, já se realizaram 6 Congressos Nacionais, que estabelecem diretrizes para o período de 5 anos. Foram, desde então, reafirmadas a necessidade das ocupações ( $2^{\circ}$ Congresso $)$, do engajamento geral na luta pela reforma agrária, do fim do latifúndio, da justiça social e da soberania popular, até a última Convenção Nacional do MST com o lema: “Lutar, Fazer Reforma Agrária Popular”. No ano de 2013, quando ocorre o $6^{\circ}$ Congresso Nacional do MST, é estabelecido esse novo objetivo: a Reforma Agrária Popular ${ }^{56}$. Essa nova concepção incorre em diversas consequências: primeiramente, que a luta pela terra não é só de interesse do

\footnotetext{
${ }^{55}$ Há inclusive, a possibilidade de se atingir graus de eficiência na exploração da terra por meio da pesquisa (artigo $8^{\circ}$, Lei 8.629). Hoje, entretanto discute-se nos movimentos sociais qual seria a função social destas pesquisas que estão sendo elaboradas, principalmente com o advento dos transgênicos ${ }^{55}$, que tem servido à uma modernização conservadora, altamente dependente de influxo de capital, voltada para o mercado de commodities, ao invés de técnicas agroecológicas que visem a autonomia dos produtores rurais.

${ }^{56}$ Programa Agrário do MST para o período 2014-2019. Pág. 40.
} 
camponês ou do trabalhador rural, mas de toda a sociedade, como forma de segurança e soberania $\operatorname{alimentar}^{57}$, com a adoção de uma matriz agroecológica $^{58}$ (que vem em momento muito apropriado, uma vez que próximo à inauguração do Plano Nacional de Agroecologia e Produção Orgânica $^{59}$ ) em contraposição à agricultura altamente concentradora de terra, altamente mecanizada (evitando assim a dependência no humano), altamente dispendiosa, que se depende de um processo financeiro creditício (e como sabemos, relacional e excludente) herdada da "Revolução Verde". Ainda se apresenta como um modelo alternativo de produção de renda, desenvolvimento tecnológico (com o surgimento e desenvolvimento de agroindústrias), de estruturação de relações pessoais/comunitárias, com produção de cultura local, além de se apresentar como um modelo econômico e social diferente, uma alternativa significante aos modos de vida hegemônicos (calcados no individualismo, no consumo), principalmente nos tempos de crise internacional.

A situação recente, como podemos observar na tabela abaixo, obtida de documento do INCRA datado de 2011 (última relação nacional de assentamentos a qual tive acesso, concedida por uma técnica) aponta para a existência até aquele momento, de 8790 Projetos de Assentamento de reforma agrária, das mais variadas espécies (Projeto de Assentamento Extrativista, Projeto de Desenvolvimento Sustentável, Projeto de Assentamento Florestal, entre outros).

\footnotetext{
${ }^{57}$ Em contraposição a um modelo de agronegócio, que além de ser gerido majoritariamente por transnacionais - o que pode ser entendido como um enfraquecimento nacional, por se tratar de questão imprescindivelmente estratégica - oferta alimentos de baixa qualidade com pouquíssima variabilidade genética, ambientalmente devastador com práticas monoculturais e com alto consumo de recursos da natureza - água, energia - visando majoritariamente o mercado externo, por meio da commoditização da produção nacional, fora o uso intensivo de agrotóxicos e mais recentemente, os Organismos Geneticamente Modificados.

${ }^{58}$ A definição de agroecologia: "uma disciplina que fornece os princípios ecológicos básicos para estudar, desenhar e manejar agroecossistemas produtivos e conservadores dos recursos naturais, apropriados culturalmente, socialmente justos e economicamente viáveis". In CALDART, Roseli Salete et alii (org). "Dicionário da educação no campo". São Paulo: Editora Expressão Popular, 2012.

${ }^{59}$ Disponível online em: file:///C:/Users/Qbex/Downloads/pageflip-3637393-80952161t_PLANO_NACIONAL_DE_AGR-379811.pdf, acessado em 09/05/2015
} 
TABELA 2: Projetos de reforma agrária e as regiões do Brasil Projetos de Reforma Agrária e as Região do Brasil

\begin{tabular}{c|c|c|c|c|c}
\hline Região do Brasil & \multirow{2}{*}{.$^{\circ}$} & \multicolumn{2}{|c|}{ Área } & \multicolumn{2}{c}{ Famílias Assentadas } \\
\cline { 3 - 6 } & Projetos & $($ ha) & $(\%)$ & $N^{\circ}$ & $(\%)$ \\
\hline Sul & 809 & $810.943,4625$ & 0,94 & 36.009 & 3,91 \\
Sudeste & 734 & $1.344 .029,2809$ & 1,57 & 40.880 & 4,44 \\
Centro-oeste & 1.576 & $9.091 .484,2922$ & 10,59 & 160.679 & 17.44 \\
Nordeste & 4.028 & $10.289 .980,1090$ & 11,98 & 307.054 & 33,33 \\
Norte & 1.634 & $64.333 .070,4056$ & 74,92 & 376.603 & 40,88 \\
\hline Total & 8.790 & $85.869 .507,5502$ & 100 & 921.225 & 100 \\
\hline Fonte: Relação dos Projetos de Reforma Agrária do INCRA (2011) -
\end{tabular}

Vale lembrar que em 1993 foi criada a Via Campesina, reunindo diversas organizações de agricultores familiares e camponeses ao redor do mundo, como estratégia de garantir não só a visibilidade dentro de um mundo globalizado, mas de estruturar maiores resistências, com ações mais eficientes. Constituindo importante ação por uma internacionalização da luta pela reforma agrária e resistência camponesa, e não só do MST, reunindo diversos grupos que lutam por estas pautas(Pastoral da Terra, Contag, CUT etc).

\section{4: O MST e a reforma agrária no Rio de Janeiro}

As primeiras intervenções fundiárias públicas remontam da década de 30. Até então não havia sido realizada nenhuma política pública de intervenção para distribuição de terras. Houve durante a década de 30 um surto sério de malária pela Baixada Fluminense, que se espalhou para a região do Norte Fluminense, num quadro bem dispersado. Os trabalhos públicos na prevenção e combate da Malária no interior do território do Estado revelou a situação degradada no qual a região se encontrava ${ }^{60}$. Em uma política pública de colonização da região rural do Estado iniciado ainda em meados de 1930, surgiram duas figuras institucionais: Núcleos Coloniais e Projeto Integrado de Colonização - PIC. Com estas foram elaborados planos de assentamento, tanto em Municípios peri-urbanos ainda

\footnotetext{
${ }^{60}$ Baseado nas informações do "Diagnóstico Regional: Diretrizes para ações de obtenção de terras em 2014" da Superintendência Regional do INCRA no Rio de Janeiro
} 
na região metropolitana da Capital: Itaguaí, Duque de Caxias, Nova Iguaçu, como forma de povoação econômica da região, além do estabelecimento de um "Cinturão Verde" que além de gerar empregos, contribuiria para estabilização da oferta de alimentos, que à época escasseava - segurança alimentar, quanto em regiões mais afastadas como forma de estabilização das regiões de Macaé, Cachoeiras de Macacu. ${ }^{61}$

Do final da década de 50 a 1964 houve, no Estado do Rio de Janeiro, a execução do Plano Piloto de Ação Agrária, que desapropriou mais de 3819 alqueires de terra. O Programa foi interrompido após o Golpe de março de 64 e maioria dos decretos desapropriatórios do período anterior, rapidamente revogados, restando largamente silenciada a luta durante o período com violenta repressão das populações rurais do Estado

Hoje (mas também historicamente), o campo Fluminense é caracterizado por uma razoável concentração fundiária impulsionada também pela forte especulação imobiliária decorrente da proximidade a uma área metropolitana em expansão. Isto acarretará no esvaziamento do campo, em um processo de êxodo rural, acelerado pela entrada do capital estrangeiro para "modernização" das monoculturas (com introdução dos eucaliptos no norte do Rio de Janeiro, por exemplo). O quadro de concentração do município de Piraí (onde se localiza o PA Roseli Nunes) não é diferente:

TABELA 3: Estrutura fundiária no município de Piraí

Estrutura fundiária no municipio de Pirai

\begin{tabular}{llll}
\hline $\begin{array}{l}\text { Tamanho } \\
\text { propriedade ha }\end{array}$ & da & $\begin{array}{l}\text { Numero } \\
\text { estabelecimentos }\end{array}$ & $\begin{array}{l}\text { de } \\
\text { Área ocupada } \\
\text { ha }\end{array}$ \\
\hline Menos de 10 & 106 & 456 \\
Entre 10 e 100 & 163 & 6705 \\
Entre 100 e 1000 & 97 & 28662 \\
Superior a 1000 & 4 & 4919 \\
\hline
\end{tabular}

Fonte: INCRA, 2007

${ }^{61}$ Ibid. 
"Segundo dados do laudo de vistoria do INCRA, as propriedades menores que 10 ha $(28,64 \%$ das propriedades) ocupam $1,12 \%$ da área, as propriedades entre $10 \mathrm{e}$ 100 ha $(44,05 \%)$ ocupam $16,45 \%$ da área, as propriedades entre 100 e 1000 ha $\mathbf{( 2 6 , 2 3 \% )}$ ocupam $\mathbf{7 0 , 3 5 \%}$ da área e as propriedades maiores de 1000 ha (1,08\%) ocupam $12,08 \%$ da área rural." 62

Assiste-se na região rural do Estado do Rio de Janeiro a falha sistemática de serviços públicos básicos, como educação, saúde, cultura e lazer, saneamento básico, estradas, comunicações, habitação, aliada a falta de crédito e ao desrespeito à legislação e precarização da situação trabalhista. O Estado está organizado em quatro regiões de ação: Norte, Região dos Lagos, Baixada e Sul Fluminense. A região Sul Fluminense, onde se localiza o assentamento, é marcada por uma ação pouco articulada, com criação de assentamentos (geralmente) dispersos o que impossibilita a criação de maiores infra-estruturas comuns. Marcante também é a forma como se tem dado a distribuição da terra na região sul do Estado, havendo concentração das terras mais produtivas pelos latifúndios e baixa capacidade de enfrentamento deste, restando as terras mais degradas para desapropriação.

No Estado do Rio de Janeiro os Assentamentos de Reforma Agrária já somam 66, totalizando 5.239 famílias. O maior Projeto de Assentamento do Estado é o denominado PA Zumbi dos Palmares onde residem 507 famílias, no Município de São Francisco de Itabapoana. O município com mais assentamentos é Campos dos Goytacazes que conta com 9 Projetos de Assentamento. Há inclusive um Projeto de Desenvolvimento Sustentável (PDS) em Macaé, criado em 2014, o PDS Osvaldo de Oliveira. Sua criação já parece influenciada pelas diretrizes da Reforma Agrária Popular, levando em consideração a agroecologia e a produção de alimentos saudáveis aliada à conservação ambiental, que é uma pauta tão importante no Estado, observado a avançada degradação do bioma Mata Atlântica nele presente, e a proximidade dos assentamentos do Estado à Unidades de Conservação,

\footnotetext{
${ }^{62}$ A tabela da estrutura fundiária do município de Piraí, assim como as informações subseqüentes são baseadas em: DA SILVA, Nivia Regina. Etnopedologia e qualidade do solo no assentamento roseli nunes, piraí-rj. Dissertação de mestrado (ciências agronômicas). Universidade Federal de Santa Catarina, 2010.
} 
zona costeira etc, este será um fator decisivo para o sucesso da reforma agrária na região.

\section{CAPÍTULO 4: ANÁLISE DO PROJETO DE ASSENTAMENTO ROSELI NUNES}

Neste capítulo passamos a analisar mais a fundo o Projeto de Assentamento (PA) Roseli Nunes em Piraí. Foram realizadas uma série de visitas para entrevistas junto à técnicos do INCRA na sua sede na cidade do Rio de Janeiro e além de duas visitas de campo ao PA Roseli Nunes.

A história do assentamento foi coletada oralmente dos assentados durante visitas de campo. A memória coletiva recapitula os eventos passados ali desde que a Fazenda, à época da desocupação chamada "Fazenda CESBRA". Uma vez integrando o patrimônio da CESBRA, o imóvel ficou sob administração desta, que entretanto, não deu utilidade suficiente ao imóvel, que não cumprindo sua função social veio a ser declarado improdutivo. Entretanto, os documentos que integram os autos do processo de desapropriação somente remontam à época na qual a propriedade do imóvel pertencia à CESBRA, desde $1987^{63}$. Esta empresa teria alterado seu nome, ao ser incorporada pela empresa canadense Brascan, para Brascan Natural Resources. Da Brascan Natural Resources então passou a integrar o patrimônio da Brascan Cattle, permanecendo durante todas estas alterações sob a direção do mesmo grupo econômico.

Foi em 2004 que por ordem da Superintendência do INCRA no exercício de suas funções regulares, determinou-se que deveria haver inspeção da Fazenda CESBRA, havendo para tanto a notificação do proprietário. Desta inspeção pela equipe técnica do INCRA resultou o LAF do imóvel. Este LAF fundamenta o Decreto Presidencial que declara de interesse social para fins de Reforma Agrária a Fazenda CESBRA, que é editado no dia 2 de dezembro de 2005. O fundamento da desapropriação foi

\footnotetext{
${ }^{63}$ Remanesce a dúvida quanto à situação da Fazenda anteriormente a esta data, uma vez que os documentos constantes nos autos do processo de desapropriação só remontam a este período.
} 
a improdutividade, mesmo havendo simultaneamente outros descumprimentos aos requisitos da função social (Lei 8.629/93 - $\operatorname{artigo} 9^{\circ}$, incisos), o que revela a preponderância do quesito produtividade sobre os demais.

Em 8 de março de 2006, 45 famílias entre militantes do MST e outros interessados na luta pela terra própria da região próxima a Piraí (Resende, Valença, Barra do Piraí, Volta Redonda), muitos trabalhadores das áreas periféricas da Baixada Fluminense, vários deles com histórico urbano, tendo trabalhado na cidade preteritamente, nas mais diversas áreas, fora do assentamento, ocupam a Fazenda CESBRA. Passados nem dois meses, ao saber da ocupação por meios de comunicação variados, o número de famílias ocupando a Fazenda Cesbra chegou a 100; em maio de 2006, houve a reintegração de posse, decretada pelo juízo de primeira instância e os ocupantes removidos da propriedade. Entretanto, os ocupantes resistiram e acamparam em frente ao imóvel na Rodovia Presidente Dutra até que, foi proposta, em 30 de novembro de 2006 a Ação de desapropriação da "Fazenda CESBRA". Apesar do prazo para imissão na posse, de acordo com a Lei Complementar $n^{\circ} 76 / 93$ ser de dois dias do despacho da inicial, a mesma só veio a ocorrer em 18 de dezembro de 2006, decisão célere, infelizmente, se comparada à média nacional de 78,5 dias ${ }^{64}$. Em 5 de janeiro de 2007, reocuparam a Fazenda, dessa vez definitivamente. O proprietário não só se recusou a sair do imóvel, como estava orquestrando a retirada do Eucalipto (para vendê-lo e não perder o investimento - ocorre que o imóvel já tinha sido desapropriado), levando os ocupantes a ocuparem a sede como forma de pressão, o que foi finalmente resolvido com um mandado de segurança.

\footnotetext{
64 “[...]as constatações feitas por Cunha Filho (2007) a partir dos dados obtidos sobre os julgamentos das ações de desapropriações no estado do Rio de Janeiro. $\mathrm{O}$ autor verificou que os juízes têm demorado em média 78,5 dias para a decisão da imissão provisória do Incra na posse, o que vem causando morosidade e paralisando a execução dos assentamentos rurais, sinalizando como mais um dos obstáculos a realização das metas da reforma agrária propostas pelo governo federal.” (Quintans, Mariana Trotta Dallalana. Poder judiciário e conflitos de terra: a experiência da vara agrária do sudeste paraense. 2011. Tese (Doutorado em Ciências Sociais) -Universidade Federal Rural do Rio de Janeiro.)
} 
Hoje são 39 famílias assentadas no PA Roseli Nunes (houve uma redução do número de famílias das 45 que no primeiro momento ocuparam o imóvel, em 2006) por meio de Contratos de Concessão de Uso celebrados junto ao INCRA. Os assentados optaram por um modelo tecnológico agrícola com referência na produção agroecológia, com o emprego de práticas conservacionistas e tradicionais (aliado ao uso de fitoterapias, que de acordo com PDA, é muito recorrente entre os assentados. ${ }^{65}$ A seguir segue um levantamento das principais produções do PA:

TABELA 4: Produção proposta no Projeto de Assentamento

Listagem de Produção proposta em ordem de citação no PA

\begin{tabular}{|l|l|l|}
\hline $\begin{array}{l}\text { Culturas de Ciclo Curto } \\
\text { ou Anuais }\end{array}$ & Culturas Permanentes & Criações \\
\hline Feijão & Laranja & Bovino de Leite \\
\hline Milho & Banana & Aves (Frango Caipira) \\
\hline Cana & Manga & Suíno \\
\hline Mandioca & Mamão & Cabra \\
\hline Hortaliças & & Pato \\
\hline Quiabo & & \\
\hline
\end{tabular}

O nome do assentamento, Roseli Nunes faz referência à uma das mártires do Movimento dos Trabalhadores sem Terra, que foi brutalmente assassinada à beira da estrada, por um caminhão que foi jogado contra uma marcha de agricultores. Por ter sido uma das pioneiras do MST, e ter dado à luz à primeira criança nascida em seu acampamento, a então chamada Fazenda Anoni, além de ter participado de diversos protestos na Capital de seu Estado, Rio Grande do Sul, durante a ditadura com forte pressão tanto governamental quanto privada para desistência, obtendo êxito na luta com a desapropriação da Fazenda Anoni em novembro de $1986 .{ }^{66}$

\footnotetext{
${ }^{65}$ Em visita ao PA Roseli Nunes, constatou-se que muitos dos assentados que já praticavam a fitoterapia nos seus espaços familiares foram capacitados em curso (do MST) para produção de produtos fitoterápicos com maior valor agregado, onde aprendem a fazer sabonetes e outros cosméticos/medicinas tradicionais com base em suas fórmulas familiares, além de aprenderam novas e trocarem experiências.

${ }^{66}$ A história de Roseli Nunes está documentada em um documentário "Terra para Rose", disponível no Youtube no endereço: https://www.youtube.com/watch?v=tbP6Ffo-sMM, acessado em 09/06/2015
} 
No caso do Roseli Nunes, como em todos os Assentamentos do Estado do Rio de Janeiro, o instituto jurídico utilizado para a distribuição daquele imóvel rural foi a Concessão de Uso (artigo 18, Lei 8.629/93).

Tendo acesso ao Laudo Agronômico de Fiscalização (LAF), que foi realizado em novembro de 2004, podemos constatar duas irregularidades constatadas resultante da visitada equipe técnica do INCRA. Podemos constatar na análise do mapa que integra o LAF (que pode ser obtido no processo do PA Roseli Nunes - Figura 1) uma síntese simplificada dos usos do imóvel à data da desapropriação. Como é apontado no mapa, a área do imóvel é de 1034,31 hectares, onde eram desenvolvidas basicamente o reflorestamento com eucalipto e a pastagem natural. Considerando a obrigação de preservar uma área mínima de 20\% do imóvel (de acordo com o artigo 16, inciso III da Lei $n^{\circ} 4.771 / 65$, que vigorava à época do LAF) a título de Reserva Legal, no caso, portanto, a área mínima de Reserva Legal da Fazenda CESBRA era de 206,8 hectares. Esta área de RL mínima é largamente extrapolada: a título de RL podemos encontrar averbados 249 hectares (quase $25 \%$ da propriedade), sendo constituída por diversos fragmentos florestais ao longo do imóvel. Portanto, em relação ao quesito Reserva Legal, a Fazenda CESBRA se encontrava regular perante, inclusive, a legislação da época (artigo 16, inciso I, Lei no ${ }^{\circ}$.771/65) (como também o seria hoje).

O Laudo de Vistoria e Avaliação foi realizado em 11 de setembro de 2006. Nele foi estipulado o valor de $\mathrm{R} \$ 2.316 .473,07$ para o imóvel, consideradas terra nua e benfeitorias. Entretanto por haverem irregularidades ambientais, houve descontos da indenização total referente à indenização no valor de R $\$ 116.520$ com base nos custos de recomposição da mata ciliar e isolamento da Reserva Legal. Durante o processo de desapropriação houve impugnações aos atos desapropriatórios, por obscuridades nos cálculos de GUT e GEE, pretensão esta afastada em âmbito de processo administrativo. 
Faz-se necessário, entretanto, levantar um ponto importante referente à Figura 1. Há neste documento o uso errôneo de algumas expressões, por não haver uma diretriz interna (que além de capacitar os agentes técnicos da Autarquia na utilização de termos legais) que uniformize a linguagem institucional, que neste caso decorre de tipos legais. Tais erros dificultam muito o entendimento, vindo a confundir até os técnicos especialistas (que não haviam participado da elaboração deste documento e não estavam a par da situação), que apesar dos obstáculos conseguiram extrair o sentido do mapa. No caso, por exemplo, a legenda aponta imprecisamente como APP prevista em lei o que na realidade é a Reserva Legal do imóvel, como se pode constatar ao observar o Licenciamento Ambiental Prévio do PA Roseli Nunes, onde se encontra como área de RL averbada valor idêntico ao declarado como APP prevista em lei pelo LAF (Figura 1). O que ainda corrobora para este entendimento é que não há uma APP mínima prevista em lei com base na área do imóvel, mas sim de acordo com a existência de algum espaço territorial definido em lei como especialmente protegido (topos de morro, margens de cursos d'água, lagos etc). Esta problemática transpareceu uma mudança de dinâmica que até então passara despercebida. Antes do NCF, um assentamento de reforma agrária requeria para sua atividade regular uma Licença Ambiental, que nestes caso era simplificada. Ao invés de três licenças (licença prévia, licença de instalação e licença de operação) eram requeridas somente a Licença Prévia (LP) seguida de uma Licença de Instalação E Operação (LIO). Hoje, entretanto, é majoritário o entendimento (inclusive por parte dos técnicos do INCRA) de que o NCF trouxe, como ferramenta de regularização ambiental o Cadastro Ambiental Rural, dispensadas as licenças de antes, que agora só se tornam obrigatórias para eventuais atividades que vierem a ser desenvolvidas no PA (como uma planta agroindustrial, ou um frigorífico, por exemplo). Tal interpretação, na realidade, decorre da Resolução do CONAMA nº 458 (que estabelece as diretrizes do licenciamento ambiental em assentamentos de reforma agrária), lá está expresso que: 
Art. $3^{\text {o }} \mathrm{O}$ licenciamento ambiental das atividades agrossilvipastoris e dos empreendimentos de infraestrutura, passíveis de licenciamento, em assentamentos de reforma agrária, será realizado pelo órgão ambiental competente.

Art. $4^{\circ}$ Serão passíveis de regularização, mediante procedimento de licenciamento ambiental simplificado, os empreendimentos de infraestrutura já existentes e as atividades agrossilvipastoris já desenvolvidas passíveis de licenciamento.

Daí se extrai o entendimento de que o licenciamento ambiental deverá ser feito para atividades específicas que venham a ser desenvolvidas no assentamento. Por estarmos em um momento de transição institucional, a adaptação às normas do NCF ainda estão se efetivando. Havia um prazo até 5 de maio de 2015 (que foi prorrogado por um ano) para a inscrição de todas as propriedades do Brasil, inclusive dos assentamentos do Rio de Janeiro, junto ao CAR. ${ }^{67}$

Já em relação às Áreas de Preservação Permanente o Laudo de Vistoria e Avaliação indica outro cenário. Identificou-se uma série de irregularidades na proteção destas áreas. De acordo com o documento, as APP's do imóvel somam, aproximadamente, 160 hectares. Entretanto identifica-se que destes 160 hectares, 26,2 hectares estão sendo utilizados como pastagem (não cumprindo portanto a função ecológica objetivada) e 80 hectares utilizados para o cultivo de eucalipto para uso industrial (o que pode ser verificado pela presença, nos autos do processo administrativo de desapropriação, de contrato de compra e venda entre a Brascan Cattle e uma empresa de revenda de madeira), que também inviabiliza a função ecológica daqueles espaços. Portanto, a Fazenda CESBRA encontrava-se em situação ambiental irregular, devido a não proteção devida de 106 hectares de APP. Neste ponto, podemos concluir, o imóvel integrava a estatística propugnada pelo Deputado Aldo Rebelo de que 90\% dos agricultores brasileiros encontravam-se, anteriormente ao NCF, irregulares.

\footnotetext{
${ }^{67}$ Como a declaração do CAR foi muito corrida suas informações não foram totalmente liberadas para análise, uma vez que ainda serão conferidas algumas informações nela contida que devem corresponder também às diretrizes do PDA e/ou do Ordenamento Territorial. Temendo haver discrepâncias entre as informações dos dois documentos, visto que ainda há prazo para aditamento das informações declaradas no CAR, os técnicos optaram por corrigi-lo antes de sua ampla divulgação. Portanto, somente trechos foram obtidos deste documento.
} 
Cabe agora analisar se as dinâmicas introduzidas pelo NCF, vieram a alterar este quadro de irregularidade.

Há, ainda uma previsão realizada no anexo 06 do LVA que prevê um investimento (abatido do valor da indenização o passivo ambiental gerado pelo desmatamento ${ }^{68}$ ) em recomposição das APP's ao longo dos cursos d’água (mata ciliar) e no cercamento das Reservas Legais.

O Módulo Fiscal no Município de Piraí corresponde a 16 hectares. Por não haverem, em Assentamentos de Reforma Agrária realizados no Estado do Rio de Janeiro, lotes individuais com área superior à um módulo fiscal (informação obtida de um técnico do INCRA), simplificou-se a dinâmica da identificação da obrigação de recomposição das áreas de Preservação permanente nas áreas rurais consolidadas, especialmente nos casos das margens dos cursos d'água naturais, onde a obrigação de recompor, no caso dos lotes individuais (uma vez que é esse o regime estabelecido no NCF para recomposição de APP em ARC, isto é, toma-se como base a área do lote individual e não do imóvel antes do parcelamento -) seria de 5 metros (artigo 61-A, $\S 1^{\circ}$ ), uma vez que os lotes individuais no PA Roseli Nunes não ultrapassam um módulo físcal. No caso das nascentes e olhos d'água perenes, o raio da APP será de $15 \mathrm{~m}$ (artigo 61-A, $\S 5^{\circ}$ ).

Em relação à Reserva Legal analisada sob o prisma do NCF, no seu artigo $12, \S 1^{\circ}$, esta será calculada com base na área do imóvel antes do fracionamento (ou seja, na sua totalidade, 1034 hectares, e não com base em cada lote individual). Além disso, em depoimento de técnico do INCRA, este afirmou que, no Rio de Janeiro, o INCRA optou por averbar as RL's de PA's em condomínio, isto é, não integrando-as a cada lote, mas como área comum do assentamento, de maneira a evitar maiores assimetrias na qualidade dos lotes e suas capacidades de uso. No assentamento houve a questão dos eucaliptos. A Fazenda

\footnotetext{
${ }^{68}$ No caso do Roseli Nunes houve um abatimento de R\$ 116.521,04 do valor total da indenização que de $\mathrm{R}$ \$ 2.316.473.07 cai para R\$ 2.199.952,03, uma vez que havia um passivo ambiental a recompor. Aproximadamente 26 hectares de APP deveriam ser recompostos, de acordo com LVA, a maioria nos cursos d'água, além do cercamento da Reserva legal (Processo de Desapropriação fl. 428
} 
CESBRA, quando gerida por seu proprietário anteriormente, havia plantado muitos eucaliptos, que possuem bom valor de mercado. Após a desapropriação, no momento do loteamento e divisão das terras do assentamento, uma grande dúvida pairava sobre ambos os técnicos e assentados: o que fazer com os eucaliptos, havendo basicamente duas possibilidades: 1) explorar todos coletivamente para, ou reinvestir no assentamento ou dividir o dinheiro entre todos os assentados equitativamente; 2) Inventariar quantos eucaliptos se encontram em cada lote individual parcelamento), e o valor estimado a ser obtido com a venda destes seja acrescido no pagamento (seguindo um pouco a lógica do $\$ 2^{\circ}$ do artigo 12 da Lei $\left.\mathrm{n}^{\circ} 8629\right)$ pelo lote. 
FIGURA 1 : Laudo de Vistoria e Avaliação (LVA)

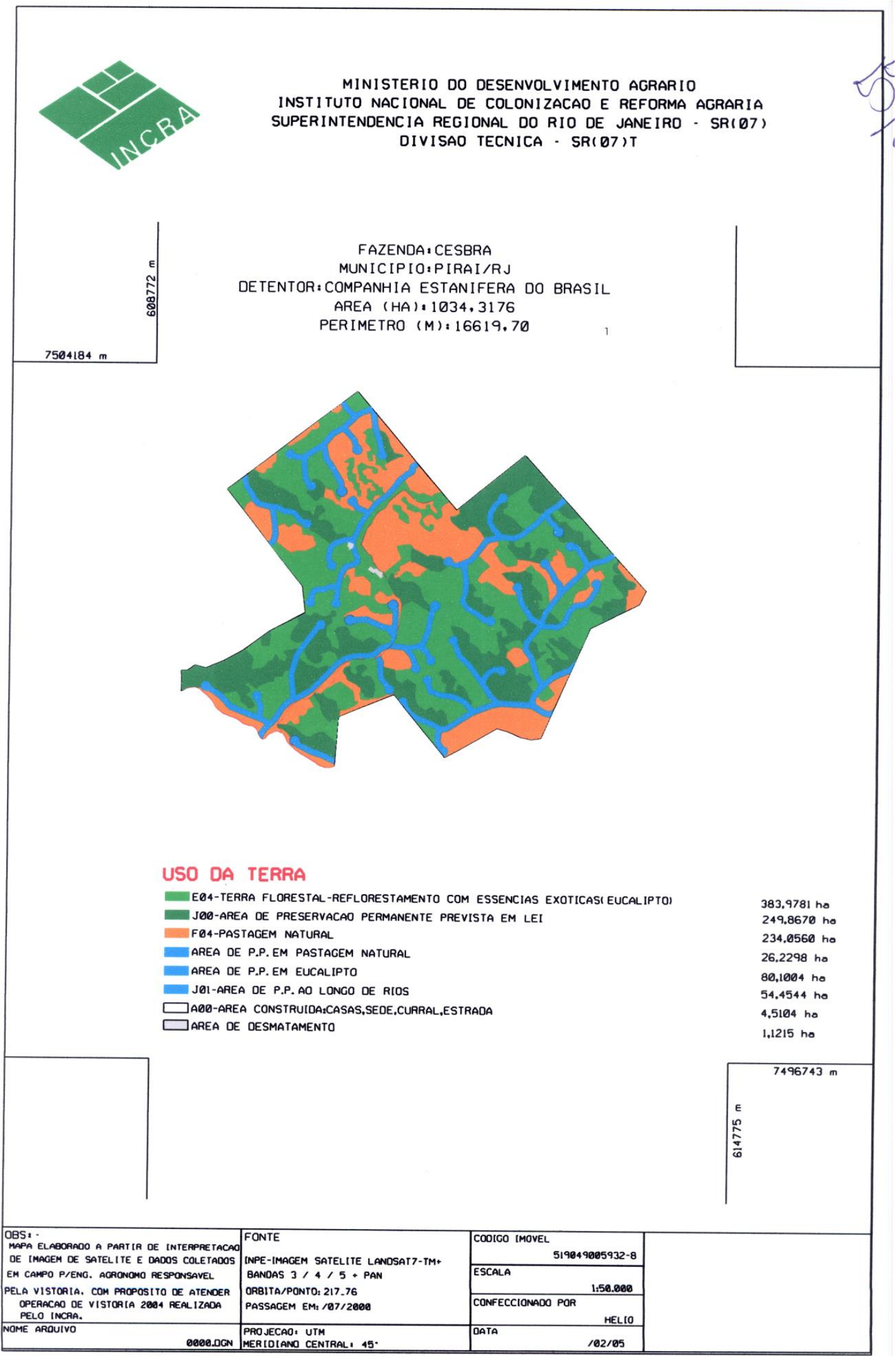

.... ICESB3xfinal1.dgn 22/2/2007 12:26:20

Fonte: INCRA 
FIGURA 2: Plano de Desenvolvimento do Assentamento - Ambiental

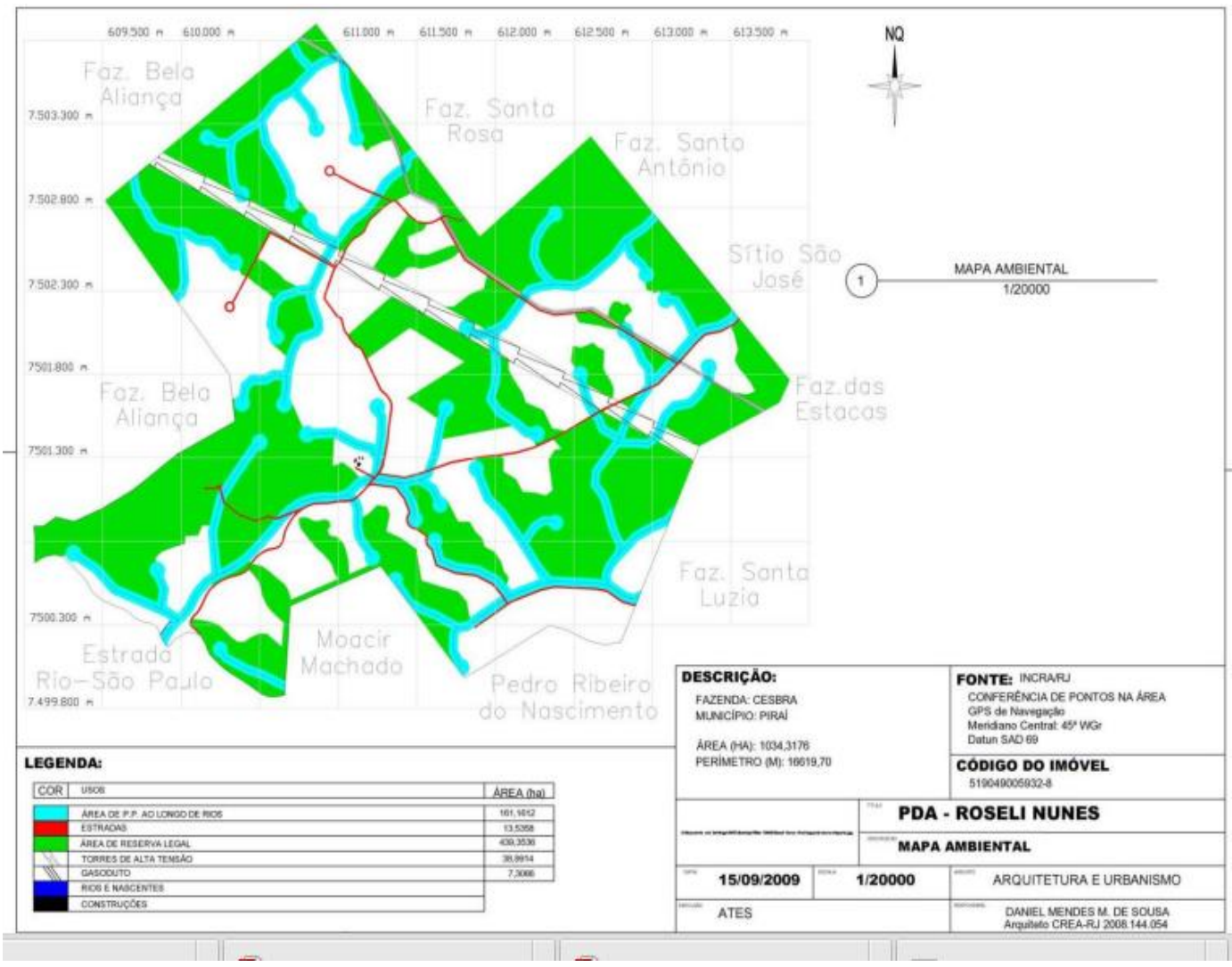

Fonte: INCRA

Há grande diferença entre os dados da Figura 1, contida no LVA, e os da Figura 2, de um segundo momento, que integra o PDA; na primeira, a área da Reserva Legal declarada seria de 149 hectares, enquanto na segunda, esta área de RL cresceu para aproximadamente 439 hectares, totalizando $42,4 \%$ da propriedade. Ainda, por se tratar de um mapa de 2009, mesmo que o documento do PDA tenha sido finalizado oficialmente em 2012, presume-se que a legislação utilizada na identificação das APP's fosse a vigente à época, no caso, o ordenamento jurídico anterior à Lei $\mathrm{n}^{\circ}$ 12.651/12. Neste caso, a APP seria, uma vez regida pela Lei $n^{\circ} 4771 / 65$, obrigatoriamente, de 30m nas bordas dos rios. Mas naqueles espaços de APP onde houve supressão da vegetação e fossem desenvolvidas atividades agrossilvopastoris até 22 de julho de 2008, se aplicada a nova legislação, só será obrigatória a recomposição de $5 \mathrm{~m}$, isto se dá devido à responsabilização pela obrigação de recompor se dará por base nos lotes individuais onde estejam presentes as irregularidades (descontado isto do 
valor total do lote a ser pago pelo assentado, como condição do contrato de uso). Uma das razões deste aumento radical foi, de acordo com a equipe que elabora o PDA ${ }^{69}$, a presença no imóvel de áreas razoavelmente grandes onde, de acordo com a Lei da Mata Atlântica (Lei nº11.428/2006), existe vegetação nativa em estágio secundário de crescimento. Para evitar eventuais irregularidades que venham a ocorrer da supressão desta, foi o caso incluí-las na RL.

A recomposição da APP deve ser feita dentro de cada lote individual, seguindo o esquema do assentamento. Entretanto o PDA representa um referencial que servirá de base tanto para o Ordenamento Territorial quanto para o (aparentemente suspenso) processo de licenciamento prévio.

FIGURA 3: Plano de Desenvolvimento do Assentamento: Loteamentos

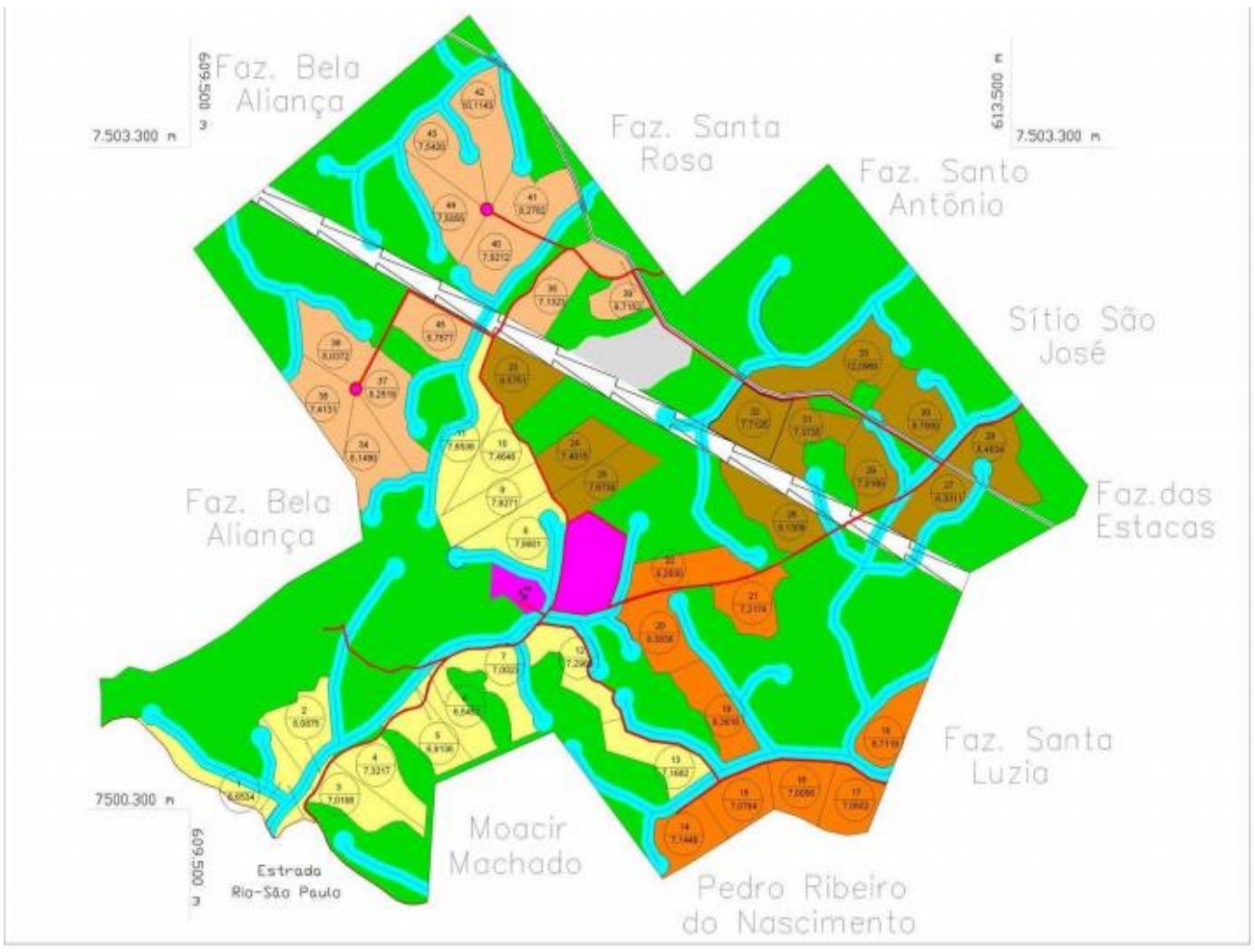

Fonte: INCRA

\footnotetext{
${ }^{69}$ Que é realizado mediante contratação de uma empresa privada, no caso do PA Roseli Nunes foi a empresa denominada "COOPERAR".
} 
O PDA, portanto, visa constituir a referência para outros documentos e procedimentos, ao mesmo tempo servindo como indicador dos anseios dos próprios assentados (uma vez que é elaborado pela equipe em imersão no assentamento). Entretanto, o PDA nem sempre se coloca como definitivo. Ele será examinado pelas equipes técnicas do INCRA ${ }^{70}$ que com base nele produzirão então um documento definitivo (normativo - cujas obrigações previstas integrarão o conjunto de obrigações do contrato de concessão de uso). Foi o caso do PA Roseli Nunes: o Ordenamento Territorial rearranjou alguns lotes entre outras modificações que viabilizassem sua ocupação regular. Para tanto recorreu-se inclusive à figura dos lotes para-rurais (cujo uso, além de ter sido banido, voltando a ser utilizado recentemente é muito incomum) isto é, lotes de menores ao módulo fiscal, onde não necessariamente seria possível tirar o sustento para toda família da atividade lá desenvolvida (no caso, estes lotes foram "reduzidos" ao para-rural para que algumas áreas não fossem loteadas irregularmente (em espaço onde não se poderia produzir) nem que se desperdiçasse área produtiva. A solução foi alocar pessoas mais idosas e sem filhos, que teriam uma capacidade física reduzida e não poderiam, mesmo que dispusezem de maiores áreas, trabalhá-las por inteiro (são áreas que varaim de pouco mais de 2 hectares até aproximadamente 4 hectares Lotes 1 a 5 do PA Roseli apresentam estas características) Portanto, a configuração definitiva do Projeto de Assentamento será definida pelo Ordenamento Territorial, exposto na FIGURA 4

\footnotetext{
${ }^{70}$ Divide-se o INCRA em duas equipes de trabalho técnico junto a assentamentos: Assentamento e Desenvolvimento.
} 
FIGURA 4: Ordenamento Territorial

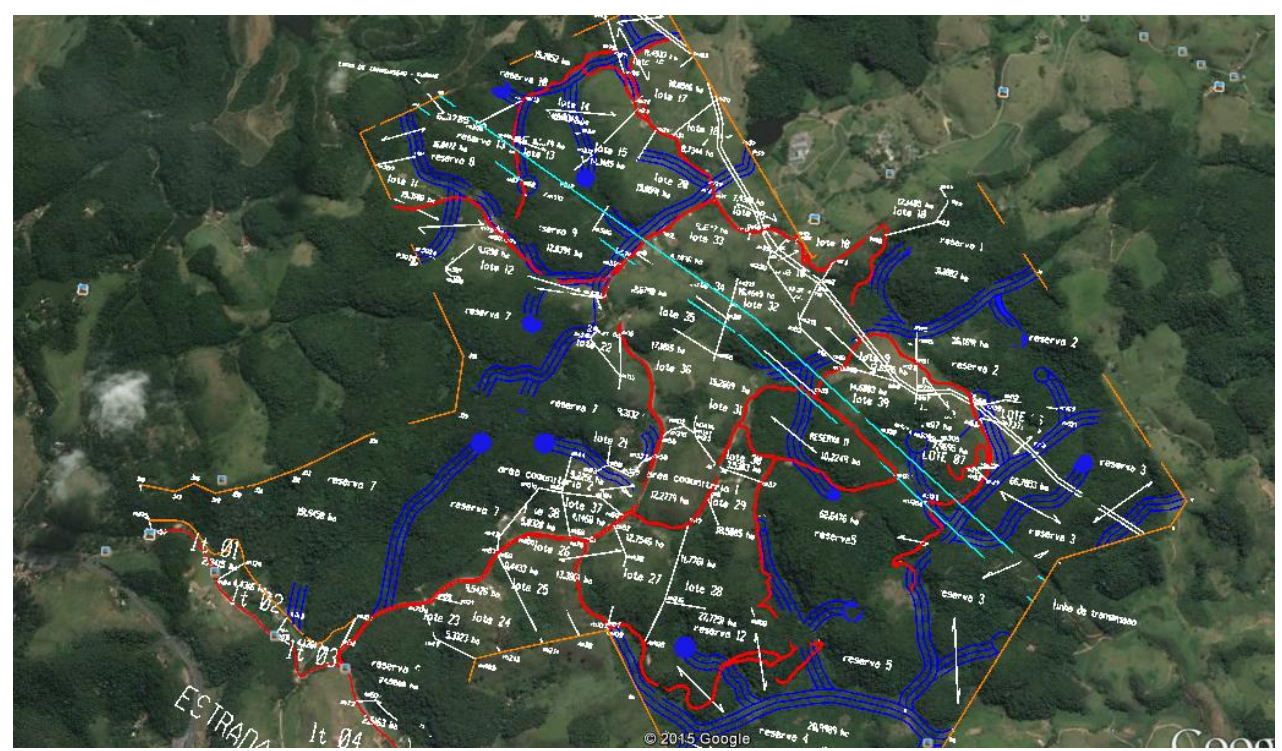

Fonte: INCRA

De acordo com o Ordenamento Territorial, há um número determinados de lotes nos quais há cursos e outros corpos d'água protegidos em Lei. A obrigação de recompor a APP terá como referência o lote onde se encontra o espaço protegido, e como base de cálculo da recomposição, a área do lote em módulos fiscais (artigo 61-C do NCF). Como a área do lote individual no Estado do Rio de Janeiro não ultrapassa 1 módulo fiscal, será portanto, de 5m a contar da margem, nas áreas onde houve a supressão da vegetação ciliar, seguida de consolidação das atividades agrossilvopastoris. No PA Roseli Nunes, portanto, deverão atentar para a recomposição os lotes 06, 07, 08, 09, 11, 12, 14, 16, 18, 19, 20, 21, 29, 31 e 32.

Enfim no dia $1^{\circ}$ de junho de 2015 foi concedido acesso à inscrição do PA Roseli Nunes junto ao Cadastro Ambiental Rural (FIGURA 5) realizada pelo INCRA (sendo sua a competência para inscrição de assentamentos de reforma agrária e quilombolas junto ao CAR). A mudança foi grande quando comparada aos documentos anteriores. O total de APP's previsto no CAR seria de 87,62 hectares e o total da Reserva Legal soma 691,5 hectares. Em relação à Área de Reserva Legal, dos 87,62 hectares que a compõe, 77,50 hectares estão em área de vegetação nativa, e portanto, 
regulares. O CAR aponta que outros 2,20 hectares de APP estão irregulares e devem ser recompostos. Portanto sobram 7,92 hectares sobre os quais o CAR silencia. Este valor corresponde à área anistiada pela nova legislação florestal (no caso, é uma área pequena, menor do que o módulo fiscal do Município de Piraí, que é de 16 hectares). Esta informação suscitou uma dúvida relevante: no LVA o passivo ambiental a ser recomposto era de 26,2 hectares. No CAR, o passivo a ser recomposto era de 2,20 hectares somados aos outros 7,92 hectares, (que ao que parece são o passivo anistiado) chega a um total de 10,12 hectares de APP suprimida. Portanto, o total de APP irregular é aproximadamente 15 hectares maior no PVA, que foi realizado em 2006 (9 anos atrás, praticamente) em comparação com o CAR (realizado no primeiro semestre de 2015 - dentro do prazo final de 5 de maio). A hipótese que se suscita aqui é a de que durante esse período houve o crescimento de vegetação nativa em boa parte das áreas que anteriormente estavam degradas/suprimidas.

FIGURA 5: Cadastro Ambiental Rural (CAR)

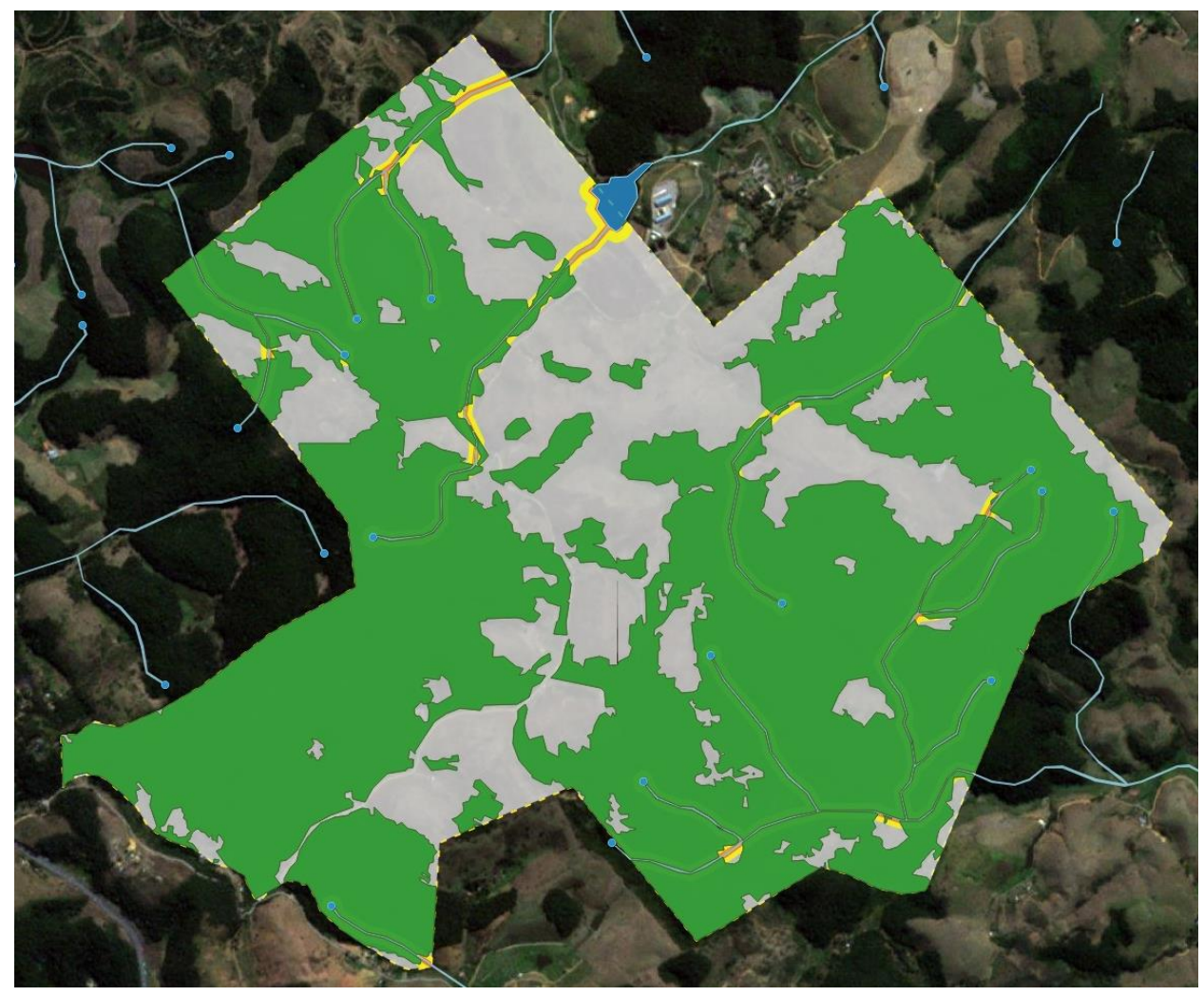

Fonte: INCRA 
Em relação à Reserva Legal, foi averbada como tal todas as reminiscências de matas nativas, sendo o valor destas reminiscências idêntico ao averbado como Reserva legal

Outra problemática detectada foi a redução da área total prevista de APP, de 160 hectares, aproximadamente, constante no LAF e LVA, para 87 hectares. Acredito identificar nesta dinâmica, ingerência da nova legislação, que permitiu o plantio de espécies exóticas de uso industrial na recomposição da APP, sendo que os 80 hectares plantados com Eucalipto em APP (desde a propriedade do imóvel pela Companhia Estanífera) passaram a ser considerados regulares, de acordo com o artigo $7^{\circ}$ do NCF. 


\section{CAPÍTULO 5: CONCLUSÃO}

$\mathrm{Na}$ presente investigação, portanto, abordou-se as mudanças nas dinâmicas da gestão do território implementadas pelo Novo Código Florestal, com enfoque para os dispositivos pertinentes à análise da adequação dos pequenos imóveis rurais, e mais especificamente, àqueles localizados em Projetos de Assentamento de Reforma Agrária. Após uma contextualização da trajetória da luta pela terra no Brasil, levantamento dos principais atores, dispositivos legais pertinentes, seus processos de formação históricos e atuais interpretações. Em seguida, ingressamos na estudo de caso em si aplicando o acúmulo das investigações anteriores na análise do Projeto de Assentamento Roseli Nunes, objetivando identificar se as mudanças recentes na legislação florestal impactaram o Assentamento e em que medida. Com os resultados desta análise retiramos uma estimativa das alterações resultantes da mutação da legislação, como forma de averiguar, no caso concreto, se esta mutação foi benéfica ao agricultor, no sentido de regularizá-lo.

Cabe portanto fazer uma retrospectiva dos dados levantados em ordem cronológica, para apontar as mudanças detectadas em basicamente 4 momentos: em um momento inicial da análise o antigo proprietário da Fazenda CESBRA, a Companhia Estanífera do Brasil, já havia averbado a Reserva Legal em torno de 196 hectares, portanto em momento anterior à desapropriação.

O segundo momento são os procedimentos do processo de desapropiação, durante a elaboração dos Laudos pela equipe técnica do INCRA constatou-se um passivo ambiental (uma irregularidade) decorrente da não conservação das Áreas de Preservação Permanente em diversos pontos do imóvel. De uma APP que deveria somar, na sua totalidade, 160 hectares, 80 hectares encontravam-se plantados com Eucalipto (indicando a 
supressão da vegetação nativa pré-existente, e, portanto, a irregularidade $)^{71}$. Outros 26 hectares onde deveria haver a vegetação da APP se encontravam tomados por pastagens, portanto havia de se falar em 106 hectares de APP irregular cuja recomposição seria obrigatória. Àquela data já havia crescido vegetação nativa, atingindo desenvolvimento secundário, por isto, elevou-se no LVA a Reserva Legal para 249 hectares. O último documento onde constam estas informações é de $2006 .^{72}$

Com o advento da Lei $\mathrm{n}^{\mathrm{o}} 12.651$ de 2012, temos o terceiro momento: é estabelecido o regime das Áreas Rurais Consolidadas. Todas os espaços em que se praticavam atividades agrossilvopastoris em APP até 22 de julho de 2008, estarão consolidados. No caso, por estarem todos dentro da área limite de um módulo fiscal, a obrigação de recomposição é de $5 \mathrm{~m}$ (tanto para rios e cursos d'água quanto para lagos e lagoas naturais ${ }^{73}$ ).

Podemos analisar o novo entendimento a partir da leitura realizada pelo Cadastro Ambiental Rural (que no caso do PA Roseli Nunes foi realizado recentemente em 2015, sendo este o quarto emais recente momento), que determinou a dinâmica da interpretação de ARC e APP: 87,6 é o total das APP's na declaração do imóvel do PA Roseli Nunes; Outros 77 hectares de APP encontravam-se em estado de conservação adequado. Importante atentar que a área de APP regular à data dos Laudos elaborados pelo INCRA apontavam em torno de 54 hectares. Isto leva a crer que o imóvel assistiu a uma proliferação razoável de sua vegetação nativa em torno de 23 hectares (apesar de ser necessário, para afirmar certamente esta informação, de uma investigação mais criteriosa acerca da questão). O CAR aponta que as únicas APP's que se encontram irregulares e devem ser recompostas somam 2,2 hectares, nas bordas dos cursos d'água. Portanto nos sobra aproximadamente 7,9 hectares que representam o que sobrou não

\footnotetext{
${ }^{71} \mathrm{O}$ que aponta para a relação de extensa irregularidade da conservação ambiental nas grandes propriedades.

${ }^{72}$ Apesar da Licença Prévia, datada de 2008, informar como área de Reserva Legal a mesma apontada pelo antigo proprietário no Registro de imóveis, portanto anterior e menos precisa que as informações do LAF e do LVA.

${ }^{73} \mathrm{O}$ imóvel conta com uma área de cursos d'água que soma 36 hectares. A área de lago corresponde a 4 hectares
} 
computado que seria devido de acordo com a legislação padrão (mínima proteção de 30 metros), mas flexibilizada na categoria ARC, reduz-se a obrigação de recompor para 5 metros. Além disso, as informações declaradas no CAR contrariam em valores relevantes as demais informações do processo de desapropriação.

Houve um "sumiço" de aproximadamente 80 hectares da declaração de APP anterior comparada a declaração do CAR, suscitando uma possibilidade: as áreas consideradas irregulares pelo plantio de Eucalipto em APP foram consideradas regulares, uma vez que havia vegetação no espaço da APP, preenchendo os requisitos legais (artigo $7^{\circ}$, Lei $\mathrm{n}^{\circ}$ 12.651/12), tornando regulares 80 hectares de APP irregular (e até retirando tal informação do cálculo).

Portanto, como podemos ver, a Lei ${ }^{\circ} 12.651$ de 2012, ao menos no presente estudo de caso, trouxe o imóvel do PA Roseli Nunes mais próximo a uma situação regular, reduzindo de 106 hectares a área irregular para apenas 2,02 hectares. Apesar de avançar na questão social, de regularização dos pequenos produtores, a nova legislação lançou mão de conceituações descaracterizantes, que por meio da desqualificação de certas categorias anteriormente definidas. Na prática, portanto, há grande discrepância entre as informações contidas nos documentos do processo de desapropriação (LAF, LVA, PAD) e as informações declaradas ao CAR, ficando uma crítica a utilização de crítérios cartográficos pouco precisos no processo de desapropriação, o que posteriormente acarretará problemas de interpretação, tanto por parte dos órgãos oficiais quanto para o entendimento da própria situação, pelos assentados. Fica a crítica em prol da uniformização dos padrões e critérios utilizados nas diversas etapas do processo de desapropriação por interesse social.Resta saber se a declaração do PA Roseli Nunes ao CAR será aprovada quando a "malha fina" do INEA passar, constituindo, este ponto, material para continuação da presente pesquisa. 
Outra conclusão importante da pesquisa diz respeito à desinformação dos assentados quanto às suas obrigações de conservação. A atuação do INCRA também não é exemplar: os técnicos do INCRA dão muitas orientações aos assentados, sem entretanto formalizar as instruções em um documento, não havendo segurança, para os assentados, quanto à legitimidade das informações, o que cria um clima de desconfiança dos assentados para com a autarquia. Há relatos de assentados que enfrentam Inquérito instaurado pelo Ministério Público refrente à supressão de Mata Atlêntica, que, afirmam os assentados, de acordo com os técnicos do INCRA, seria área produtiva e suprimível. A susgestão dos próprios assentados é que cada lote receba uma cópia do mapa do terreno, indicando as áreas produtivas e restrições ao uso, o que além de informar, serviria como garantia jurídica contra eventuais excessos do Poder Público. Os assentados também se quixam de não terem sido consultados, visitados nem informados sobre o Cadastro Ambiental Rural do PA Roseli. Neste, além de diversas inconsistências (oriundas em muitos casos - se não em todos - da não observação do local, mas antes de um monitoramento remoto burocrático: crítica extensível também ao procedimento de parcelamento dos lotes, muitos deles tendo sua produção comprometida por um planejamento desvinculado das realidades topográfica e social - lotes cortados por brejos, lotes que serpenteiam entre outros lotes, o que obriga o assentado à passar por lote alheio para ter acesso à parte do seu) quanto à identificação de matas, eucaliptos suprimíveis, localização (ou mesmo a existência) de nascentes onde impera a imprecisão ${ }^{74}$, há também a falta da identificação de "excludentes de ilicitude ambiental". Por exemplo, muitos dos lotes que apresentam as mais extensas irregularidades ambientais são cruzados pelo gasoduto que atravessa o PA Roseli Nunes. Quando este cruza um curso d'água ocasiona um alagamento (encharcamento) da área,

\footnotetext{
${ }^{74}$ Lembrando que as referências topográficas e hidrográficas são de levantamentos nacionais das décadas de 60-70; houve no CAR pequena correção destes. Alguns rios deixaram de existir desde então e outros surgiram, mas estes últimos não foram incluídos, enquanto os primeiros foram excluídos.
} 
causando uma distorção não só do corpo hídrico como da APP que deveria margeá-lo. Além disso a passagem do gasoduto no local impede o plantio de árvores para a recomposição ambiental: a não identificação destes pontos cruciais acarreta uma responsabilização indevida dos assentados que se veêm impotentes diante de tal acusação. $\mathrm{O}$ mesmo se aplica às estradas que cortam o assentamento e impedem o livre fluxo dos cursos d'água, ocasionando alagamentos, além da irregularidade; vale frisar que neste caso, é responsabilidade do INCRA instalar a infra-estrutura comum do assentamento, quando não há concorrência do poder municipal (para se for o caso, na situação em tela, construir ponte que permita o fluxo d'água).

Por fim, ainda se queixam os assentados de sua incapacidade de proteger as àreas de Reserva Legal do assentamento contra desmatamento da mata e caça de animais silvestres por forasteiros. A ausência de mapas (que precisem os limites dos lotes e do próprio assentamento, considerado em conjunto) e informações sobre o próprio assentamento (somado à atitude omissiva do Poder Público local em face à estas denúncias) além de impedir uma efetiva proteção contra ameaças externas, abre brechas para que os próprios assentados, por ignorância, incorram em irregularidades. 


\section{BIBLIOGRAFIA}

AB'SÁBER, Aziz Nacib. Do Código Florestal para o Código da Biodiversidade. Carta pública. São Paulo, 2010.

BALESTRIN, Diego, BALBINOT, Rafaelo e VALERIUS, Jaqueline. Código Florestal e aplicações práticas na pequena propriedade rural. In: Revista do Centro do Ciências Naturais e Exatas da Universidade Federal de Santa Maria, v. 14 n. 14 Set. 2013.

BENJAMIN, Antônio Herman. Hermenêutica do Novo Código Florestal. In: Doutrina : edição comemorativa, 25 anos. Brasília: Superior Tribunal de Justiça, 2014.

CALDART, Roseli Salete et ali (org). Dicionário da educação no campo. São Paulo: Editora Expressão Popular, 2012.

CARTER, Miguel (org.). Combatendo a desigualdade social : MST e a Reforma Agrária no Brasil, São Paulo, Editora UNESP, 2010.

MEDEIROS, Leonilde Servolo. Reforma agrária no Brasil: História e atualidade da luta pela terra. São Paulo. Editora Fundação Perseu Abramo, 2003.

LEAL, Victor Nunes. Coronelismo, Enxada e Voto: o município e o regime representativo no Brasil. São Paulo. Editora Companhia das Letras, 2012

LOUZADA, Rovena Vasconcellos. Modalidades de Projeto de Assentamento Rural: Evolução e Legislação Federal. 2011. Monografia (Graduação em Engenharia Florestal) - Universidade Federal Rural do Rio de Janeiro

MESQUITA, Rodrigo Alcantara. Legislação Ambiental Brasileira. Uma Abordagem Descomplicada. Rio de Janeiro: Editora Quile, 2012.

MILARÉ, Edis. Direito do Ambiente. Editora Revista dos Tribunais, 2014 PILATTI, Adriano. Marchas de uma Contramarcha: Transição, UDR e Constituinte. 1988. Dissertação (Mestrado em Direito) - Pontifícia Universidade Católica do Rio de Janeiro. 
MST, Programa Agrário do MST para o período de 2014-2019

INCRA/Cooperar Projeto de Desenvolvimento do Assentamento Roseli Nunes. Documento elaborado pela empresa Cooperar sob requerimento do INCRA. Piraí, 2012.

QUINTANS, Mariana. A Magistratura Fluminense: seu olhar sobre as ocupações do MST. 2005. Dissertação (Mestrado em Direito) - Pontifícia Universidade Católica do Rio de Janeiro.

ROBOREDO, Delmonte e BERGAMASCO, Sônia Maria Pessoa Pereira. Recuperação Socioambiental de Agroecossistemas: Questões e desafios para sua viabilização. In Retratos de Assentamentos, volme 16, n.1, 2013. SANTOS, Gilda Diniz dos (Org). Lei 8629/93 comentada por procuradores federais: uma contribuição da PFE/INCRA para o fortalecimento da reforma agrária e do direito agrário autônomo. Brasília: INCRA, 2011.

SILVA, José Afonso da. Curso de Direito Constitucional Positivo. 35a. edição - São Paulo: Ed. Malheiros, 2011.

INCRA. Diagnóstico Regional: Diretrizes para ações de obtenção de terras em 2014 